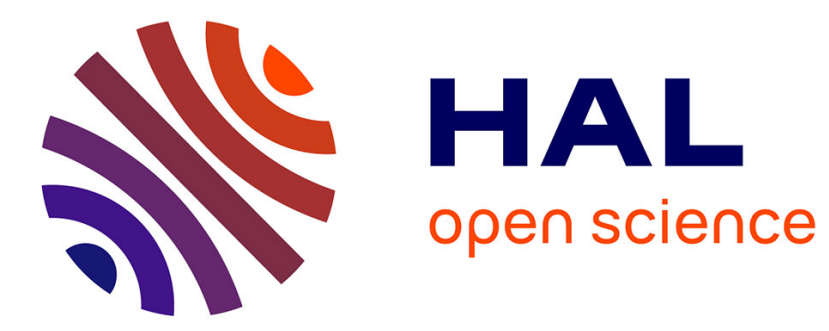

\title{
Phytoplankton distribution in the Western Arctic Ocean during a summer of exceptional ice retreat
}

Pierre Coupel, H. Y. Jin, Diana Ruiz-Pino, J. F. Chen, S. H. Lee, H. L. Li, Mehrad Rafizadeh, Véronique Garçon, Jean-Claude Gascard

\section{To cite this version:}

Pierre Coupel, H. Y. Jin, Diana Ruiz-Pino, J. F. Chen, S. H. Lee, et al.. Phytoplankton distribution in the Western Arctic Ocean during a summer of exceptional ice retreat. Biogeosciences Discussions, 2011, 8, pp.6919-6970. 10.5194/BGD-8-6919-2011 . hal-00920237

\section{HAL Id: hal-00920237 \\ https://hal.science/hal-00920237}

Submitted on 16 Dec 2015

HAL is a multi-disciplinary open access archive for the deposit and dissemination of scientific research documents, whether they are published or not. The documents may come from teaching and research institutions in France or abroad, or from public or private research centers.
L'archive ouverte pluridisciplinaire HAL, est destinée au dépôt et à la diffusion de documents scientifiques de niveau recherche, publiés ou non, émanant des établissements d'enseignement et de recherche français ou étrangers, des laboratoires publics ou privés. 
Biogeosciences Discuss., 8, 6919-6970, 2011

www.biogeosciences-discuss.net/8/6919/2011/

doi:10.5194/bgd-8-6919-2011

(C) Author(s) 2011. CC Attribution 3.0 License.

\section{Phytoplankton distribution in the Western Arctic Ocean during a summer of exceptional ice retreat}

P. Coupel ${ }^{1}$, H. Y. Jin ${ }^{2}$, D. Ruiz-Pino ${ }^{1}$, J. F. Chen ${ }^{2}$, S. H. Lee ${ }^{3}$, H. L. Li ${ }^{2}$, M. Rafizadeh ${ }^{1}$, V. Garçon ${ }^{4}$, and J. C. Gascard ${ }^{1}$

${ }^{1}$ Laboratoire d'Océanographie et du Climat, Expérimentation et Approches Numériques (LOCEAN-UPMC), UMR7159, CNRS - INSU, Paris, France

${ }^{2}$ Laboratory of Marine Ecosystem and Biogeochemistry, Second Institute of Oceanography, SOA, PRC, Hangzhou 310012, China

${ }^{3}$ Department of Oceanography, Pusan National University, Busan, South Korea

${ }^{4}$ LEGOS, UMR5566, CNRS, 18 Avenue Edouard Belin, 31401, Toulouse Cedex 4, France

Received: 24 June 2011 - Accepted: 3 July 2011 - Published: 13 July 2011

Correspondence to: P. Coupel (pclod@locean-ipsl.upmc.fr)

Published by Copernicus Publications on behalf of the European Geosciences Union.

Phytoplankton distribution in the Western Arctic Ocean

P. Coupel et al.

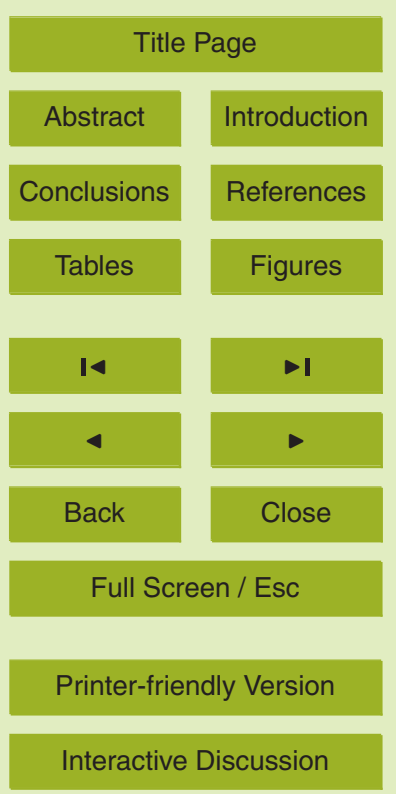




\section{Abstract}

A drastic ice decline in the Arctic Ocean, triggered by global warming, could generate rapid changes in the upper ocean layers. The ice retreat is particularly intense over the Canadian Basin where large ice free areas were observed since 2007. The CHINARE 52008 expedition was conducted in the Western Arctic (WA) ocean during a year of exceptional ice retreat (August-September 2008). This study investigates whether a significant reorganization of the primary producers in terms of species, biomass and productivity has to be observed in the WA as a result of the intense ice melting. Both pigments (HPLC) and taxonomy (microscopy) acquired in 2008 allowed to determine the phytoplanktonic distribution from Bering Strait $\left(65^{\circ} \mathrm{N}\right)$ to extreme high latitudes over the Alpha Ridge $\left(86^{\circ} \mathrm{N}\right)$ encompassing the Chukchi shelf, the Chukchi Borderland and the Canadian Basin.

Two different types of phytoplankton communities were observed. Over the ice-free Chukchi shelf, relatively high chl-a concentrations $\left(1-5 \mathrm{mg} \mathrm{m}^{-3}\right)$ dominated by $80 \%$ of diatoms. In the Canadian Basin, surface waters are oligotrophic $\left(<0.1 \mathrm{mg} \mathrm{m}^{-3}\right)$ and algal assemblages were dominated by haptophytes and diatoms while higher biomasses $\left(\sim 0.4 \mathrm{mg} \mathrm{m}^{-3}\right)$ related to a deep Subsurface Chlorophyll Maximum (SCM) are associated to small-sized (nano and pico) phytoplankton. The ice melting onset allows to point out three different zones over the open basin: (i) the ice free condition characterized by deep and unproductive phytoplankton communities dominated by nanoplankton, (ii) an extended $\left(78^{\circ}-83^{\circ} \mathrm{N}\right)$ Active Melting Zone (AMZ) where light penetration associated to the stratification start off and enough nutrient availability drives to the highest biomass and primary production due to both diatoms and large flagellates, (iii) heavy ice conditions found north to $83^{\circ} \mathrm{N}$ allowing light limitation and consequently low biomass and primary production associated to pico and nanoplankton.

To explain the poverty (Canadian Basin) and the richness (Chukchi shelf) of the WA, we explore the role of the nutrient-rich Pacific Waters, the bathymetry and two characteristics linked to the intense ice retreat: the stratification and the Surface Freshwater
BGD

8, 6919-6970, 2011

\section{Phytoplankton distribution in the Western Arctic Ocean \\ P. Coupel et al.}

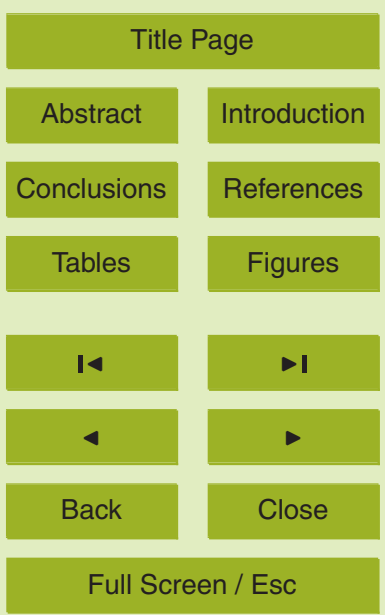

Printer-friendly Version

Interactive Discussion 
Layer (SFL). The freshwater accumulation induced a strong stratification limiting the nutrient input from the subsurface Pacific waters. This results in a biomass impoverishment of the well-lit layer and compels the phytoplankton to grow in subsurface.

The phytoplankton distribution in the Chukchi Borderland and north Canadian Basin, 5 during the summer of exceptional ice retreat (2008), suggested when compared to in-situ data from a more ice covered year (1994), recent changes with a decrease of the phytoplankton abundance while averaged biomass was similar. The 2008 obtained phytoplankton data in the WA provided a state of the ecosystem which will be useful to determine both past and future changes in relation with predicted sea ice decline.

\section{Introduction}

The recent exceptional decline and thinning of Arctic sea ice cover (Rothrock et al., 1999; Lindsey and Zhang, 2005; Stroeve et al., 2007; Comiso et al., 2008) forced by greenhouse gases emissions has put the Arctic Ocean in the centre of international scientific attention (Wassmann et al., 2010). Models predict that sea ice will continue to shrink in the coming years and that near ice-free conditions could be reached by summer 2040 (Holland et al., 2006; Overland and Wang, 2007). Numerous physical changes have been emphasized in the Arctic such as the effects of ice retreat and temperature increase. However, only a few studies are concerned by the direct impact of ice retreat on primary producers, basis of the marine trophic chain and key players in the carbon cycle through the biological pump (Longhurst and Harrison, 1989). Because of heavy ice conditions in the central Arctic, biogeochemical studies were mainly confined to the Arctic and sub-Arctic shelves (Barents Sea, Bering Sea, Chukchi Sea). Only a few oceanographic campaigns, Arctic Ocean Section (AOS, 1994), Surface HEat Budget of the Arctic (SHEBA, 1997), The RUSsian-American Long-term Census of the Arctic (RUSALCA, 2004) and Beringia, 2005 took place in the high Arctic latitudes, mainly composed of the deep basins.

All these studies highlight the strong influence of environmental factors (ice, irra-
BGD

8, 6919-6970, 2011

\section{Phytoplankton distribution in the Western Arctic Ocean \\ P. Coupel et al.}

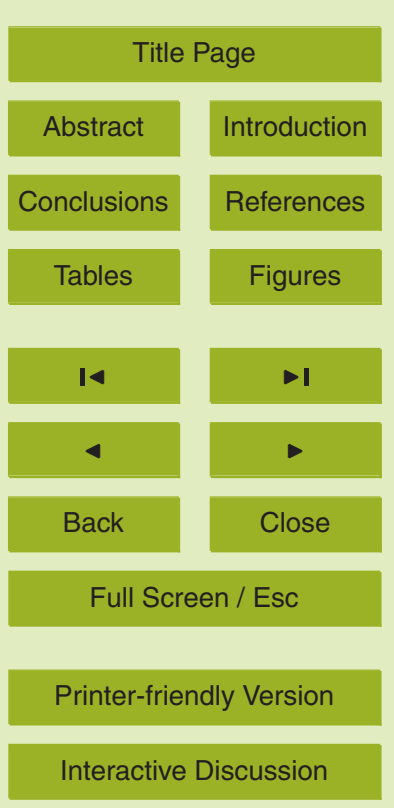


diance, stratification, nutrients supply) on Arctic ecosystems yielding a high spatiotemporal variability of the primary production. During the spring bloom, Arctic shelves become one of the most productive areas of the world ocean (Walsh, 1989; Sakshaug et al., 1994; Springer et al., 1996; Rysgaard et al., 2001; Sakshaug, 2003) sustain5 ing extremely rich fisheries and a large variety of marine mammals and migratory bird communities (ACIA, 2005). The spring bloom rapidly depletes the nutrients in surface and leads to post-bloom conditions characterized by a Subsurface Chlorophyll Maximum (SCM, Cota et al., 1996; Hill and Cota, 2005). Offshore, oligotrophic conditions prevail due to ice cover and low nutrients concentrations (Gosselin et al., 1997). In 10 1994, during AOS, first measurements in the central Arctic (ice cover $>90 \%$ ) estimate the ice algae contribution to $57 \%$ of the total primary production (Gosselin et al., 1997). Ice-algae production was mainly composed (50 to $100 \%$ ) by large cells ( $>5 \mu \mathrm{m}$ ) while the contribution of small cells primarily prasinophytes adapted to dark conditions and low nutrients dominated the phytoplankton assemblage in the water column (Hill et al., 15 2005).

With the rapid environmental changes occurring in the Arctic Ocean, these ecological patterns will be reorganizing. Satellite observations suggest an increase of the primary production and phytoplankton biomass relative to an increase of open-water area and longer ice-free periods correspond to a longer phytoplankton growing season (Arrigo et al., 2008; Pabi et al., 2008). However, the sea-ice reduction acts at the expense of ice algae habitat (Wassmann et al., 2010) and could decline the benthic biomass and bottom-feeding communities by limiting the carbon export to the sediments (Piepenburg, 2005; Grebmeier et al., 2006a). The timing and species composition of the spring bloom of phytoplankton appears to have been delayed by early ice retreat in the Bering Sea (Hunt et al., 2002). With record level of ice retreat observed in the early 21st century (ACIA, 2005; Stroeve et al., 2005), a northward shift of the subarctic/arctic boundary is possible, together with the northward migration of competitive species into the warmed environments (Grebmeier et al., 2006b). In the 1990s, large blooms of coccolithophores occurred over much of the Bering Sea shelf (Vance et al.,
BGD

8, 6919-6970, 2011

\section{Phytoplankton distribution in the Western Arctic Ocean \\ P. Coupel et al.}

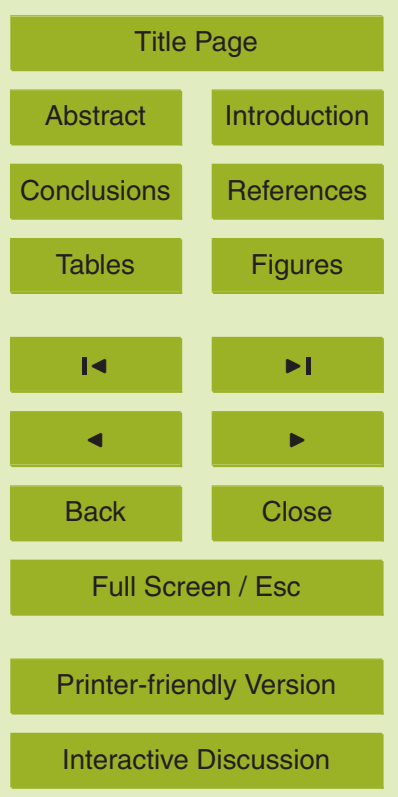


1998; Napp and Hunt, 2001; Stockwell et al., 2001) where diatoms typically dominate the phytoplankton biomass (Sukhanova and Flint, 1998).

There is a crucial need of multidisciplinary programs to observe the on-going changes occurring in the Arctic ecosystems especially in the Arctic deep basins recently released from the ice in summer. Since a decade, the Chinese National Arctic Research Expedition (CHINARE) undertook a series of oceanographic campaigns $(1999,2003,2008$ and 2010) conducted on-board the icebreaker Xuelong. The CHINARE cruises allow to get in situ data of physics (ice, salinity, temperature, irradiance), biogeochemistry (nutrients, oxygen) and biology (phytoplankton) to monitor the 10 evolution of the Western Arctic (WA). We will document here the spatial distribution of the phytoplankton communities in the water column during the CHINARE 2008 cruise (August and September 2008, Fig. 1b). Hydrological and biogeochemical observations will allow to elucidate the underlying mechanisms coupling the physical and chemical environment with the primary producer distribution. The CHINARE 2008 cruise covered a large range of latitudes from $65^{\circ} \mathrm{N}$ to $86^{\circ} \mathrm{N}$ and took place during a summer of exceptional ice retreat (Fig. 2a) comparable to 2007 conditions (Stroeve et al., 2007). For the very first time, phytoplankton observations, pigments, primary production and taxonomy, were provided in recent ice-free basins. Most of the stations presented an ice coverage lower than $70 \%$ while all stations located south of $75^{\circ} \mathrm{N}$ was ice-free (Figs. 1b, 2a and b). Only samples collected north of $85^{\circ} \mathrm{N}$ presented a heavy ice pack with ice concentrations higher than $90 \%$.

Experimental protocols are described (Sect. 2) before the hydrological conditions in the Chukchi Shelf and the Canadian Basin and a detailed description of the pigments assemblages and associated phytoplankonic groups (Sect. 3). The transition between the various biogeochemical regimes from the shelf towards the northern latitudes is discussed together with the impact of recent environmental changes on the phytoplankton distribution in the polar ocean (Sect. 4). Last objective will be assessed by comparing the present state (2008) with the one deduced from previous field studies before summer sea decline fast in the WA.
BGD

8, 6919-6970, 2011

\section{Phytoplankton distribution in the Western Arctic Ocean \\ P. Coupel et al.}

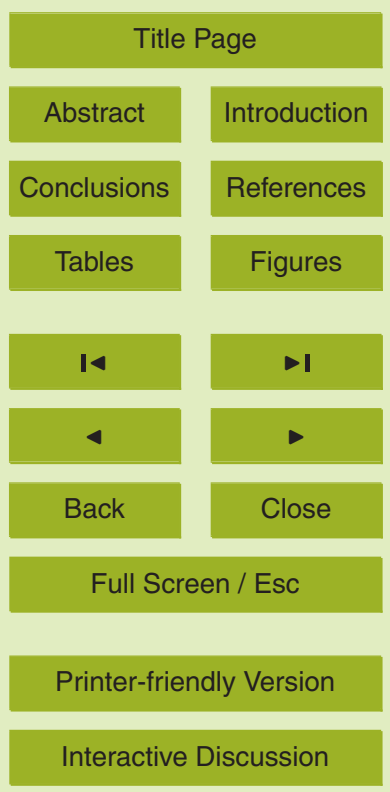




\section{Materials and methods}

\subsection{Hydrological and ice data}

During the cruise of the XueLong from 1 August to 8 September 2008, a conductivitytemperature-depth (CTD) system (Sea-Bird SBE 9) mounted on a 24-place rosette 5 samplers with 10 I Niskin Bottles was used for the sampling of 85 stations (Fig. 1b). Accuracy of temperature and conductivity acquired were $0.01{ }^{\circ} \mathrm{C}$ and $0.001 \mathrm{~S} \mathrm{~m}^{-1}$, respectively, and associated resolution $0.001^{\circ} \mathrm{C}$ and $0.0001 \mathrm{~S} \mathrm{~m}^{-1}$. The surveys were made over the continental Chukchi shelf early August and then crossed the Canadian Basin until the Alpha Ridge in 19 August (Fig. 1a). After a 10 days ice camp at $85^{\circ} \mathrm{N}$, the icebreaker went south through the Chukchi Borderland to finally return to the Chukchi shelf in September 2008.

Ice concentrations were obtained from the Special Sensor Microwave Imager (SSM/I) daily satellite data (level 2 products at $12.5 \mathrm{~km}$ spatial resolution) by collocation in time and space with the CHINARE 2008 CTD stations. At each CTD station, the average ice concentration over the last seven days was produced (Fig. 2b) as well as an estimate of the number of days with ice-free conditions (Fig. 2c) and of the numbers of days with ice concentration lower than $90 \%$ (Fig. 2d) since the visit of the Xuelong at that station. We consider here the onset of melting and cracking of sea ice as the moment when the ice concentration has decreased below $90 \%$.

\subsection{Nutrients and AOU}

The determination of nitrate $\left(\mathrm{NO}_{3}^{-}\right)$and nitrite $\left(\mathrm{NO}_{2}^{-}\right)$is based on the method described by Wood et al. (1967), acid orthosilicic $\left(\mathrm{Si}(\mathrm{OH})_{4}\right)$ was measured according to Grasshoff et al. (1983) and phosphate $\left(\mathrm{PO}_{4}^{3-}\right)$ according to Gordon et al. (1993). Preparation of primary standards and reagents were done following the WOCE protocol (Gordon et
BGD

8, 6919-6970, 2011

\section{Phytoplankton distribution in the Western Arctic Ocean \\ P. Coupel et al.}

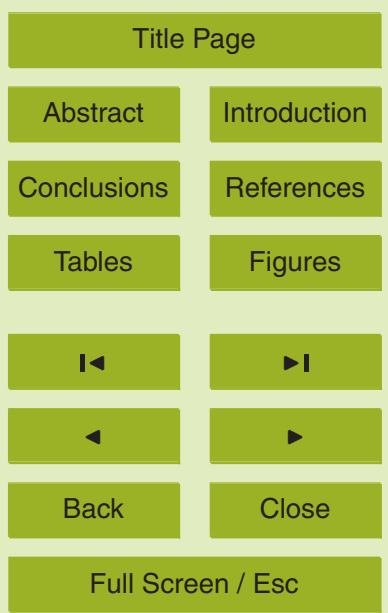

Printer-friendly Version

Interactive Discussion

uous Flow AutoAnalyzer (SKALAR, The Netherlands) and are expressed in $\mu \mathrm{M}$ (for 
$\mu \mathrm{mol} \mathrm{kg}{ }^{-1}$ ) in the current manuscript. The accuracy of the analytical system for nutrient concentrations in water samples was $\pm 0.02 \mu \mathrm{M}$ for phosphate and nitrite and $\pm 0.1 \mu \mathrm{M}$ for nitrate, ammonium and silicate. Acid orthosilicic $\left(\mathrm{Si}(\mathrm{OH})_{4}\right)$ will be called silicate $(\mathrm{Si})$ for easy reading. Considering nitrates as the most limiting nutrient for phytoplankton 5 in the WA (Cota et al., 1996; Gosselin et al., 1997), the nutricline will be determined by the position of the nitracline. The position of the nutricline in the water column was evaluated from each spline of vertical nitrate concentrations profile by the position of the inflexion point (Fig. 3d). The AOU (Apparent Oxygen Utilization) in micromol/kg is calculated from the solubility following the algorithm expression from Brenson and 10 Krause (1984).

\subsection{Pigments}

Pigment samples were collected at 65 stations for 2 or 3 different depths: surface $(3 \mathrm{~m})$, SCM based on in situ fluorescence vertical profiles and sometimes a second SCM. Phytoplankton pigments were acquired by filtering samples (2I of seawater) through $25 \mathrm{~mm}$ Whatman GF/F filters (pore $0.7 \mu \mathrm{m}$ ). Filters were stored in a freezer at $-80^{\circ} \mathrm{C}$ to avoid biological degradation. HPLC (High Performance Liquid Chromatography) analysis was performed in SOA (Second Institute of Oceanography, Hangzhou, China) following the method developed by Van Heukelem and Thomas (2001). Pigments were extracted from the filters during $1 \mathrm{~h}$ at $-20^{\circ} \mathrm{C}$ in $100 \%$ methanol and sonicated in an ultra-sonic bath to disrupt cells. An internal standard, the DL- $\alpha$ Tocopherol acetate, was added to the solvent extracts to correct pigment concentrations from recovery. Pigments were analysed using a Waters 600E HPLC and an Eclipse C8 column $(150 \times 4.6 \mathrm{~mm})$ thermostated at $60^{\circ} \mathrm{C}$ and a flow rate of $1 \mathrm{ml} \mathrm{min}^{-1}$. Every 30 samples, a standard mixture was analysed under the same conditions. Standards were purchased from Sigma Chemical Company and from DHI, Institute for Water and Environment, Denmark. The concentration of chlorophyll-a (chl-a) and chlorophyll- $b$ $(\mathrm{chl}-b)$ standards was determined by spectrofluorometry using published extinction
BGD

8, 6919-6970, 2011

\section{Phytoplankton distribution in the Western Arctic Ocean \\ P. Coupel et al.}

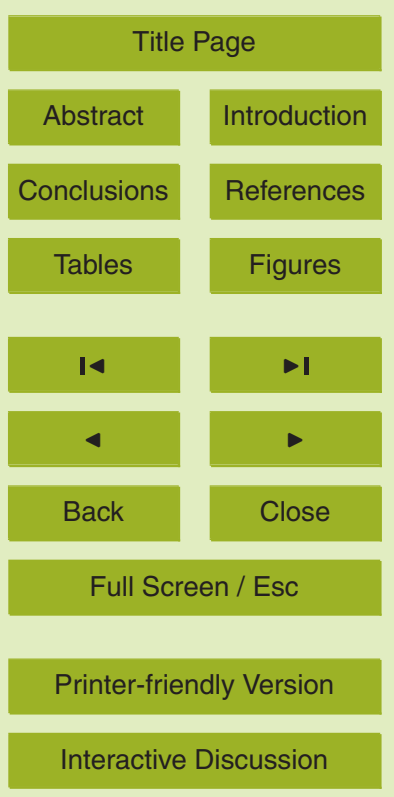


coefficients (Jeffrey and Humphrey, 1975). Identification and quantification of chl-a and 17 accessory pigments (Table 1) were calculated in the samples based on retention time and peak size in chromatograms. Pigments concentrations and their ratios to chl-a allow to estimate the relative contribution of different phytoplankton commu5 nities using the CHEMTAX (CHEMical TAXonomy) software (Mackey et al., 1996). Twelve pigments (fucoxanthin, peridinin, alloxanthin, 19-butanoyloxyfucoxanthin, 19hexanoyloxyfucoxanthin, zeaxanthin, lutein, chlorophyll- $b$, chlorophyll-a, neoxanthin, prasinoxanthin, violaxanthin) are used as biomarkers to determine eight phytoplankton classes: diatoms, dinoflagellates, Chrysophytes, Prymnesiophytes, prasinophytes, 10 cryptophytes, chlorophytes and cyanobacteria. Phytoplankton biomass can be separated in different size classes (microphytoplankton $>20 \mu \mathrm{m}$; nanophytoplankton 2$20 \mu \mathrm{m}$; picophytoplankton $<2 \mu \mathrm{m}$ ) according to Ras et al. (2008).

\subsection{Species composition analysis of phytoplankton}

Water samples $(100 \mathrm{ml})$ for species composition analysis of phytoplankton were ob15 tained from Niskin bottles mounted on CTD/rosette samplers, preserved with glutaraldehyde (final concentration 1\%), and filtered through Gelman GN-6 Metricel filters $(0.45 \mu \mathrm{m}$ pore size, $25 \mathrm{~mm}$ diameter). The filters were mounted on microscope slides with water-soluble embedding media (HPMA, 2-hydroxypropyl methacrylate) onboard. Returned back to home laboratory, the HPMA slides were used to estimate cell 20 abundance and identify phytoplankton species, based on the same scheme of Lee et al. (2011). At least 300 cells were analyzed using a microscope (BX51, Olympus) with a combination of light and epifluorescence at $400 \times$ for microplankton and at $1000 \times$ for pico- and nanoplankton.

\subsection{Nitrogen and carbon uptake rates of phytoplankton}

Daily and carbon uptake rates were determined using the same a ${ }^{13} \mathrm{C}$ isotope tracer technique previously applied in the Arctic Ocean (Lee et al., 2011b). In brief, seawater
BGD

8, 6919-6970, 2011

\section{Phytoplankton distribution in the Western Arctic Ocean \\ P. Coupel et al.}

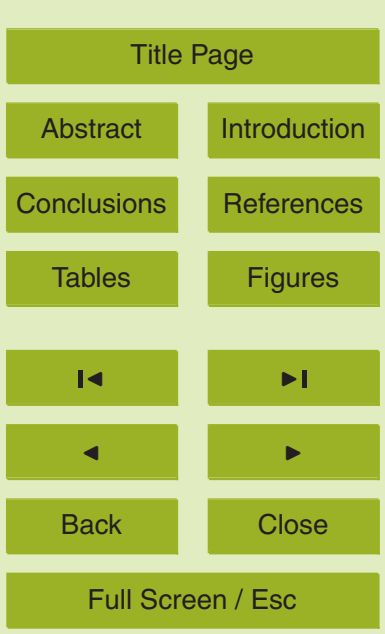

Printer-friendly Version

Interactive Discussion 
samples at each light depth $(100,50,30,12,5$, and $1 \%)$ were transferred from the Niskin bottles to 1 I polycarbonate incubation bottles covered with stainless steel screens to simulate each light depth. Then, heavy isotope-enriched (98-99\%) solutions of $\mathrm{H}^{13} \mathrm{CO}_{3}$ were added to the samples. The bottles were incubated in a deck 5 incubator under natural light conditions cooled with surface seawater. The 4 to $5 \mathrm{~h}$ incubations were terminated by filtration through pre-combusted $\left(450^{\circ} \mathrm{C}\right) \mathrm{GF} / \mathrm{F}$ filters $(24 \mathrm{~mm})$. The filters were immediately frozen and preserved for mass spectrometric analysis at the stable isotope laboratory of the University of Alaska Fairbanks, US.

\section{Results}

\subsection{The physical environment}

Based on bathymetry, the study area is divided into three geographical provinces. The Chukchi shelf (CS, Fig. 1a) is associated to shallow depths $(<100 \mathrm{~m})$ and edged by a continental slope in the North and an abrupt shelf-break in the North-East (Fig. 1b). The Chukchi Borderland, considered as a mid-depth $(\sim 1000 \mathrm{~m})$ extension of the

Chukchi shelf, is a complex area composed by the Chukchi Abyssal Plain (CAP), the Chukchi Cap (CC) and the Northwind Ridge (NR). The deep basins (1000 m to $4000 \mathrm{~m}$ ) are composed of the Canadian Abyssal Plain (CB), the Mendeleev Abyssal Plain (MAP) and the Alpha Ridge (AR). Pacific Waters (PW) enter in the Arctic Ocean through Bering Strait are driven over the CS through two main currents (Coachman et al., 1975). The cold nutrient-rich Anadyr Waters (AW, Fig. 1a) flows to the north and the Alaskan Coastal Current (ACC) carries warmer and nutrients depleted waters to the east along the Alaskan coast (Paquette and Bourke, 1974; Ahlnäs and Garrison, 1984). Basin circulation is driven by the anticyclonic Beaufort Gyre (BG); the center of the gyre was evidenced by a freshwater accumulation resulting from Ekman convergence (Proshutinsky et al., 2009). In summer 2008, surface salinity observations (Fig. 4b) suggested the center of the BG to have a southern position around
BGD

8, 6919-6970, 2011

\section{Phytoplankton distribution in the Western Arctic Ocean \\ P. Coupel et al.}

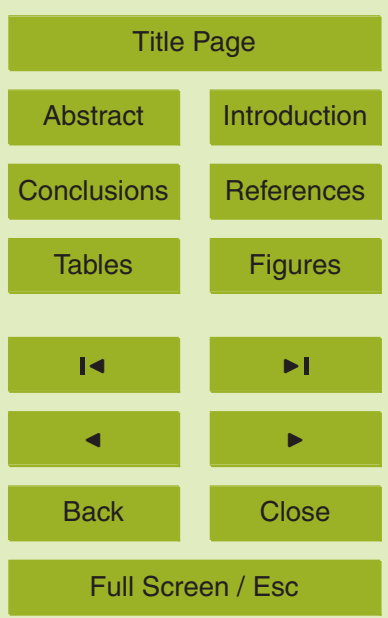

Printer-friendly Version

Interactive Discussion 
$74^{\circ} \mathrm{N}, 145^{\circ} \mathrm{W}$ in accordance with hydrographic surveys of salinity and dynamic height from the BGEP (Beaufort Gyre Program data project, McLaughlin and Carmack, 2010).

During the CHINARE 2008 cruise, 64 stations presented ice free conditions $(<20 \%$ of ice, Fig. 2b), 19 stations were partially ice covered (20\% to $70 \%$ of ice) and 6 sta5 tions were sampled in heavy ice conditions ( $>70 \%)$. Ice free conditions were observed over the CS, the CAP and the CB south of $76^{\circ} \mathrm{N}$. Partial ice cover was encountered between latitude $76^{\circ} \mathrm{N}$ and $84^{\circ} \mathrm{N}$ and in the shelf-break region in August. Finally, heavy ice cover was only observed over the AR, north of $84^{\circ} \mathrm{N}$. Whereas the south of the CS and the south of the $\mathrm{CB}$ are released from ice more than 30 days before the visit of the 10 icebreaker (Fig. 2c), the melting of ice over the Chukchi Borderland occurred between August and September, only 10 days before measurements started. This area recently impacted by the ice melting over the Chukchi Borderland will be called Active Melting Zone (AMZ) in this article because of these specific hydrographic conditions (Fig. 2b).

The water column of the WA is characterized by an exceptional wide range of salin15 ity from 24 to 35 and a temperature varying from near-freezing point to $7^{\circ} \mathrm{C}$ (Fig. $3 \mathrm{a}$ ). The highest variability in terms of temperature and salinity is observed in the upper $30 \mathrm{~m}$, strongly affected by solar radiation, river inflow and melting of sea ice. Below the surface layer and down to $250 \mathrm{~m}$ depth, the water column exhibits a strong salinity gradient which characterized the halocline layer (HL, Fig. 3a). The halocline structure 20 is modified in an upper (UH, Fig. 3b) and a lower halocline (LH) by the subsurface circulation of the buoyant PW $(32<S<33.5)$. The UH is associated to a subsurface $T_{\max }$ $\left(-1{ }^{\circ} \mathrm{C}<\theta<-0.5^{\circ} \mathrm{C}\right)$ located between $50 \mathrm{~m}$ to $100 \mathrm{~m}$ and linked to the inflow of Pacific Summer Water (PSW) while the $\mathrm{LH}$ is associated to a $T_{\min }\left(\theta<-1.4^{\circ} \mathrm{C}\right)$ between 100 and $200 \mathrm{~m}$ linked to the injection of Pacific Winter Water (PWW). The PSW flowing in the Arctic only during the summer period is warmed $\left(\theta>1{ }^{\circ} \mathrm{C}\right)$ and depleted in nutrients during its way across the Bering Sea (Aagaard and Roach, 1990; Weingartner et al., 1998). The PWW affected by cooling, ice formation and sediments remineralization during winter, are traced in summer 2008 by a silicate maximum ([Si] $=20-$ $40 \mu \mathrm{M}$, Fig. 12c) centered on salinity 33.1 and near-freezing temperature $\left(\theta<-1.4^{\circ} \mathrm{C}\right)$

\section{BGD}

8, 6919-6970, 2011

\section{Phytoplankton distribution in the Western Arctic Ocean \\ P. Coupel et al.}

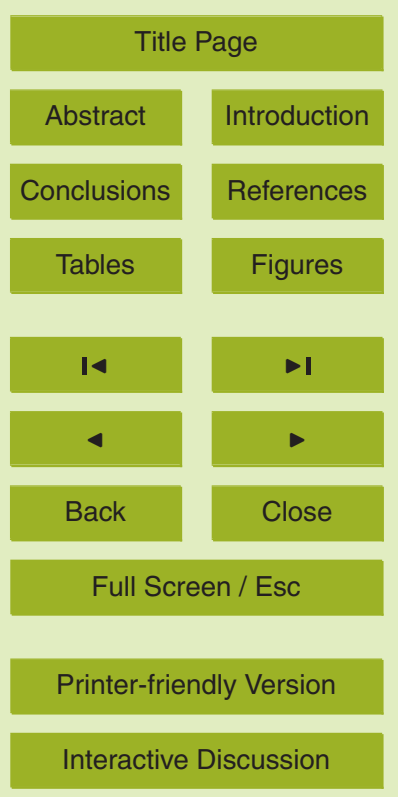


in agreement with Aagaard et al. (1981) criteria. The PW flowing in the Arctic in 2008 are characterized by a low N/P ratio of $6: 1$ (Fig. 3c) comparatively to the canonical N/P Redfield ratio in the ocean of 16:1 (Redfield et al., 1963) which highlights the deficiency of the Arctic uppers layers in nitrate. Below the halocline, the thermocline layer (TL,

5 Fig. $3 a$ and b) located between $200 \mathrm{~m}$ to $300 \mathrm{~m}\left(34<S<34.8,-0.7>\theta>0{ }^{\circ} \mathrm{C}\right)$ is characterized by a temperature gradient marking the transition with the Atlantic Layer (AL) lying at depth $300 \mathrm{~m}$ to $1000 \mathrm{~m}\left(34.5<S<34.9, \theta>0{ }^{\circ} \mathrm{C}\right)$ and the Arctic Deep Water (ADW $>1000 \mathrm{~m}, S \sim 34.95, \theta<0^{\circ} \mathrm{C}$ ).

The surface temperature increase from less than $0^{\circ} \mathrm{C}$ in the ice-covered area to $6{ }^{\circ} \mathrm{C}$ 10 in the ice-free areas (Fig. 4a) in relation $(R=0.84)$ with the time of exposure to solar radiation (ie number of days with ice-free conditions, Fig. 2c). The surface salinity (Fig. $4 b)$ was relatively high over the shelf $(S \sim 32)$ and decreased over the basins $(S<30)$ due to a large accumulation of freshwater from rivers and sea-ice meltwater. The lowest salinity is measured in the ice-free basins and especially in the center of the

BG $(S \sim 24)$ where the anticyclonic motion accumulates freshwater (Proshutinsky et al., 2009). The depth of the polar mixed layer (PML, Fig. 4c), defined as the depth were the vertical gradient of density $\left(\sigma_{t}\right)$ is higher than $0.05 \mathrm{~kg} \mathrm{~m}^{-3}$ does not exceed $25 \mathrm{~m}$ during the expedition. The PML is reduced to a layer thinner than $10 \mathrm{~m}$ in ice free or sparsely ice covered area. The thickness of the mixed layer slightly increased in presence of ice from 10 to $20 \mathrm{~m}$ in partially ice covered areas (20-90\% of ice) and close to $25 \mathrm{~m}$ when ice coverage was larger than $90 \%$ north of $85^{\circ} \mathrm{N}$. The stratification of the upper part of the water column is estimated through a stratification index ( $\mathrm{SI}$ in $\left.\mathrm{kg} \mathrm{m}^{-3}\right)$, Fig. 4d) which represents the difference of density between the surface and a depth of $100 \mathrm{~m}$. An anti-correlation between surface salinity and SI $(R=-0.87$, not shown) emphasized the tight relation between the accumulation of freshwater in surface and the increase of the stratification. The weakest stratification is observed over the shelf $\left(\mathrm{SI}<3 \mathrm{~kg} \mathrm{~m}^{-3}\right)$ and increased in offshore stations $\left(\mathrm{SI}>3 \mathrm{~kg} \mathrm{~m}^{-3}\right)$ especially in the ice free basins where the highest stratification is observed $\left(\mathrm{SI}=5-8 \mathrm{~kg} \mathrm{~m}^{-3}\right)$. In this study, the freshwater content of the upper layer called Surface Freshwater Layer (SFL, Fig. 5a) is associated
BGD

$8,6919-6970,2011$

\section{Phytoplankton distribution in the Western Arctic Ocean \\ P. Coupel et al.}

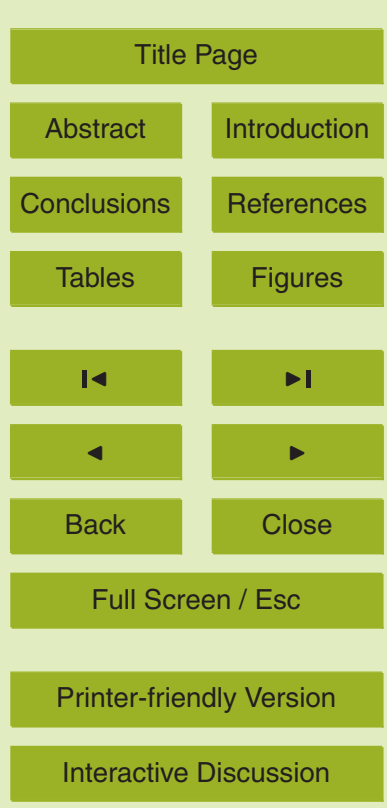


to the layer where salinity is lower than 31 . The SFL was 10 to $20 \mathrm{~m}$ thick over the shelf and around $40 \mathrm{~m}$ thick offshore. The highest freshwater ( $S F L>60 \mathrm{~m}$ ) accumulation is observed in the center of the BG and north of $83^{\circ} \mathrm{N}$. In contrast the south of the MAP presents the thinner SFL $(20 \mathrm{~m})$ of the offshore stations, close to the values observed 5 over the shelf.

\subsection{Nutrients and chlorophyll-a distributions}

The nutricline was shallower than $20 \mathrm{~m}$ over the CS and in the south of the MAP (Fig. $5 \mathrm{~b}$ ), deepened over the Chukchi Borderland $(40 \mathrm{~m})$ and reached a maximum depth in the northern part of the $C B$ and in the center of the BG $(60 \mathrm{~m})$. Figure $5 \mathrm{c}$ presents the averaged nitrate concentration in the euphotic layer and reflects the nitrate availability for phytoplankton. Water column averaged nitrate concentrations were lower than $2 \mu \mathrm{M}$ in the $\mathrm{CB}$ and near to Point Hope over the shelf (Fig. $5 \mathrm{c}$ ). The highest nitrate availability was observed in the north of the shelf, partially ice-covered, with averaged nitrate concentrations close to $6 \mu \mathrm{M}$ in the euphotic layer. In the Chukchi borderland and south of the CS nitrate concentrations were also relatively high $(3-5 \mu \mathrm{M})$.

Except for the southern CS, all sampled stations presented a SCM (Fig. 6b). The depth of the SCM varied from $20 \mathrm{~m}$ in the CS to $80 \mathrm{~m}$ in the center of the BG (Figs. 5e, $6 a)$. Chl-a exhibits the highest concentration over the continental shelf with an average of $0.85 \mathrm{mg} \mathrm{chl}-\mathrm{am}^{-3}$ at surface $(3 \mathrm{~m})$ and $1.5 \mathrm{mg} \mathrm{chl}-\mathrm{am}^{-3}$ at SCM (Fig. $5 \mathrm{~d}, 5 \mathrm{f}$,

20 6b). Although offshore stations present biomass at the SCM three times lower than over the shelf, chl- $a$ concentrations $\left(\sim 0.4 \mathrm{mg} \mathrm{chl}-a^{-3} \mathrm{~m}^{-3}\right)$ remain relatively high for the open ocean. In contrast, offshore surface waters present very low chl-a concentrations $\left(<0.1 \mathrm{mg} \mathrm{chl}-\mathrm{a} \mathrm{m}^{-3}\right)$, ten times lower than over the continental shelf.
BGD

8, 6919-6970, 2011

\section{Phytoplankton distribution in the Western Arctic Ocean \\ P. Coupel et al.}

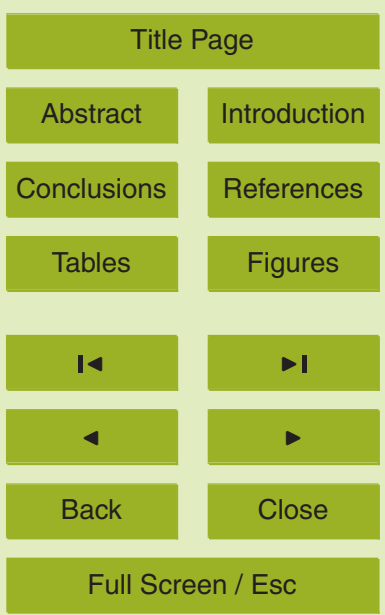

Printer-friendly Version

Interactive Discussion 


\subsection{Spatial variability of phytoplankton biomass, pigments and functional groups}

Hydrological and biogeochemical variability observed during the CHINARE 2008 cruise define quite naturally two systems, the shelf (CS) and the basins (CB and Chukchi 5 Borderland) separated by a transition zone formed by a continental slope and/or an abrupt shelf-break. These systems drive different phytoplankton biomass and functional groups.

\subsubsection{Chukchi shelf, shelf-break and continental slope}

In early August 2008 , the south of the CS $\left(<68^{\circ} \mathrm{N}\right)$ presents high surface $(2-5 \mu \mathrm{M})$ and 10 sub-surface $(5-10 \mu \mathrm{M})$ nitrate concentrations (Fig. 3d). High surface chl-a concentration reaching $3 \mathrm{mg} \mathrm{chl}-\mathrm{a} \mathrm{m}^{-3}$ measured at station $\mathrm{R} 03$ (Fig. 6b) are associated to a relative abundance of Fucoxanthin (Fuco) higher than $85 \%$ (Fig. 7a). In the north of the CS $\left(>68^{\circ} \mathrm{N}\right)$, nitrates are reduced in the upper $10 \mathrm{~m}(<1 \mu \mathrm{M}$, Fig. $3 \mathrm{~d})$ but reached elevated concentrations deeper than $20 \mathrm{~m}(>5 \mu \mathrm{M})$. Biomasses are decreased in the 15 low nutrients surface layer $\left(\sim 0.5 \mathrm{mg} \mathrm{chl}-\mathrm{a} \mathrm{m}^{-3}\right)$ and SCM is observed at around $15 \mathrm{~m}$ with concentrations varying between 1 to $5 \mathrm{mg} \mathrm{chl}^{-a \mathrm{~m}^{-3}}$. Partially ice covered station R13 in the Central Canyon $\left(73^{\circ} \mathrm{N}\right)$ showed a subsurface accumulation of nutrients, between $20 \mathrm{~m}$ and $100 \mathrm{~m}$ with concentrations of $15 \mu \mathrm{M}$ and $60 \mu \mathrm{M}$ for nitrate and silicate, respectively (Fig. $11 \mathrm{e}$ and $\mathrm{f}$ ) associated to a peak of chl-a (5 $\mathrm{mg} \mathrm{chl}-\mathrm{a} \mathrm{m}^{-3}$,

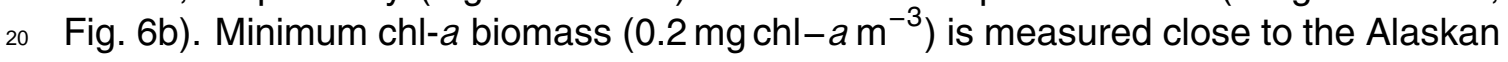
coast $(\mathrm{R} 05, \mathrm{C} 23)$ and associated to a decrease of the Fuco relative abundance (40\%) while the importance of accessory pigments characteristic of small-sized phytoplankton like Prasinoxanthin or Pras (15\%), Chlorophyll- $b$ or Chl- $b(15 \%)$ and Neoxanthin or $\mathrm{Neo}(5 \%)$ increased. When crossing the continental slope (west of $160^{\circ} \mathrm{W}$ ) or the shelf crease by a factor two in sub-surface and by a factor three at surface. However, local high chl-a concentrations $\left(\sim 1.5 \mathrm{mg} \mathrm{chl}-\mathrm{a} \mathrm{m}^{-3}\right)$ are observed near $40 \mathrm{~m}$ at the mouth of

\section{BGD}

8, 6919-6970, 2011

\section{Phytoplankton distribution in the Western Arctic Ocean \\ P. Coupel et al.}

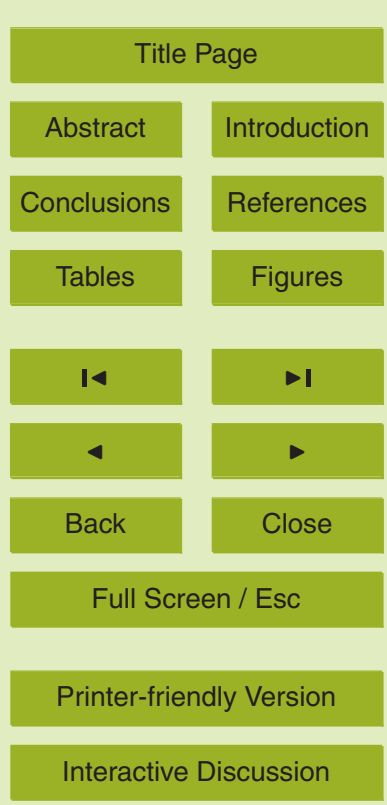


Central Canyon (R17) and Barrow Canyon (S24). High pigments ratios of 19HF (52\%) and $\mathrm{Chl}-b(48 \%)$ are measured in the shelf break/slope transition between the shallow shelf waters $(<200 \mathrm{~m})$ and the deep basins waters $(>200 \mathrm{~m})$.

CHEMTAX analysis revealed the dominance of diatoms over the CS, represent5 ing $71 \%$ and $82 \%$ of the phytoplanktonic biomass at surface and SCM, respectively (Fig. 8). The highest dominance of diatoms was observed where chl-a concentrations were the highest. Prasinophytes, cryptophytes and haptophytes (prymnesiophytes + chrysophytes) represent $13 \%, 7 \%, 4 \%$ of the phytoplankton assemblage at surface and $5 \%, 4 \%, 5 \%$ at SCM. Dinoflagellates and cyanobacteria represent less than $103 \%$ in both depths. Local enhancement of the relative abundance of prasinophytes $(25 \%)$, cryptophytes $(20 \%)$ and dinoflagellates (10\%) are observed in the low chlorophyll coastal waters of Alaska.

\subsubsection{Open Arctic (Canadian Basin and Chukchi Borderland)}

Offshore, the chl-a concentrations in surface waters ranged from 0.01 to $0.30 \mathrm{mg}$ chl$15 \mathrm{a} \mathrm{m}^{-3}$ with a mean of $0.09 \pm 0.08 \mathrm{mg} \mathrm{chl}-\mathrm{am}^{-3}$ (Figs. $5 \mathrm{~d}, 6 \mathrm{~b}$ ). The lowest surface chl-a concentrations $\left(0.01-0.10 \mathrm{mg} \mathrm{chl}-\mathrm{a} \mathrm{m}^{-3}\right)$ are measured in the $\mathrm{CB}$, the $A R$ and the CAP and increased $\left(0.10\right.$ to $\left.0.30 \mathrm{mg} \mathrm{chl}-a^{-3}\right)$ in the MAP, over the CC and at Barrow Canyon. Fuco is the most represented accessory pigments in the surface waters of the open Arctic (37\%, Fig. 7a) and dominates (40-100\%) over the ice cov20 ered part of the CB and over the slope and Barrow Canyon. The ice free part of the $\mathrm{CB}$ exposed to the light $24 \mathrm{~h}$ a day was associated to the lowest surface biomass $\left(0.03 \pm 0.03 \mathrm{mg} \mathrm{chl}-\mathrm{a} \mathrm{m}^{-3}\right)$ and dominated by the photoprotecting Diadino pigments (Fig. 7a). The surface waters of the Chukchi Borderland were co-dominated by the picoplankton associated pigments Chl- $b$ (30\%), Pras (10\%) and the microplankton re-

25 lated pigments Fuco (25\%). The 19HF pigments were also well represented at most of the stations (12\%) reaching the highest contribution over the slope and in Barrow Canyon.

BGD

8, 6919-6970, 2011

\section{Phytoplankton distribution in the Western Arctic Ocean \\ P. Coupel et al.}

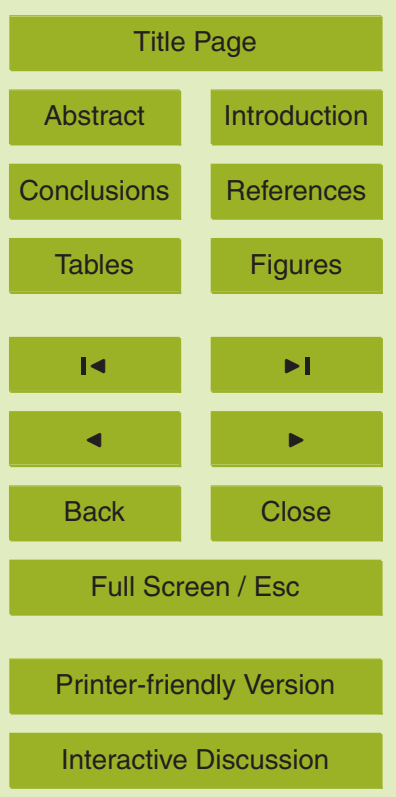


At the SCM, chl-a concentrations ranged from 0.05 to $1.00 \mathrm{mg} \mathrm{chl}-\mathrm{am}^{-3}$ with a mean of $0.40 \pm 0.28 \mathrm{mg} \mathrm{chl}-\mathrm{am}^{-3}$ (Figs. $5 \mathrm{f}, 6 \mathrm{~b}$ ). The Fuco represented $22 \%$ of the accessory pigments at the SCM and Chl- $b, 19 \mathrm{HF}$ and 19BF represent $24 \%, 20 \%, 5 \%$ respectively, of the pigments relative abundances (Fig.7b). Diadino signal becomes 5 negligible $(1.5 \%)$ while the quantities of Prasino are 5 times higher than in surface (16\%). Chl-c3+c2, Neo and Caro are observed in proportion between $1 \%$ and $5 \%$ whereas the other pigments are found in trace quantities $(<1 \%)$. The ice-free southern area of CB presents the deepest SCM (>60 m, Figs. 5e, 6a) associated to highly vari-

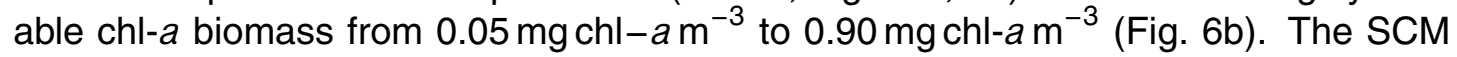
10 were shallower $(30-50 \mathrm{~m})$ in the north of the CB and exhibited average chl-a concentrations of $0.49 \pm 0.09 \mathrm{mg} \mathrm{chl}-\mathrm{a} \mathrm{m}^{-3}$ when ice cover varied between $30 \%$ to $70 \%$ and of $0.20 \pm 0.11 \mathrm{mg} \mathrm{chl}-\mathrm{a} \mathrm{m}^{-3}$ for ice cover higher than $70 \%$ over AR. The chl-a concentrations was relatively high $\left(0.5 \pm 0.25 \mathrm{mg} \mathrm{chl}-\mathrm{a} \mathrm{m}^{-3}\right)$ in the Chukchi Borderland where the SCM depth was shallow $(20-40 \mathrm{~m})$. Accessory pigments assemblages underline 15 slight increases of the Chl- $b$ relative abundance from $20 \%$ in the CB to $30 \%$ in the Chukchi Borderland whereas the signal of $19 \mathrm{HF}$ was twice as high eastward (CB) than westward (Chukchi Borderland).

The CHEMTAX analysis (Fig. 8) in offshore stations revealed the dominance of diatoms in the surface waters with more than $50 \%$ of relative abundance at most of the stations. An exception was observed in the surface waters of the MAP where prasinophytes (40\%), chrysophytes (30\%) and chlorophytes (15\%) were well represented. At the SCM, diatoms were 3 times less abundant than at surface and represented $15 \%$ of the phytoplankton communities. The prasinophytes and chrysophytes represented the two major phytoplankton groups with $45 \%$ and $30 \%$, respectively, of the relative

abundance offshore. Prasinophytes contribution exceeds $60 \%$ in the western part of the Arctic study area and chrysophytes with $40-70 \%$ of the relative contribution are the main phytoplankton group in deep SCM of the ice-free CB. The prymnesiophytes reach a significant contribution of the SCM communities in some stations located near bathymetric features such as the Chukchi shelf edge or north-east of CC (P80, N81).

BGD

8, 6919-6970, 2011

\section{Phytoplankton distribution in the Western Arctic Ocean \\ P. Coupel et al.}

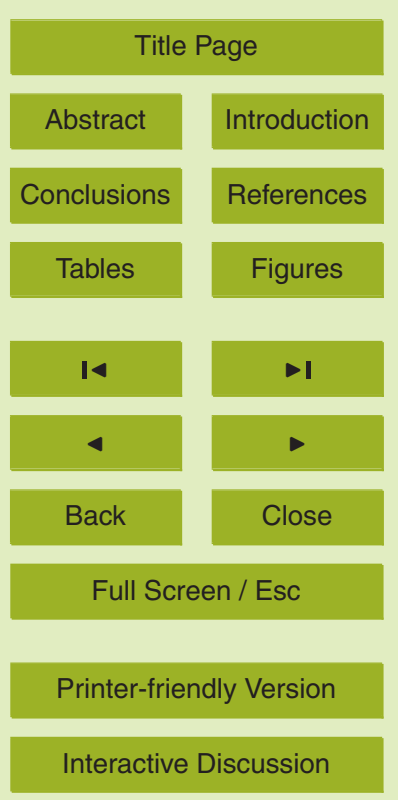

Interactive Discussion 
In summary, two distinct regimes occurred in the WA: - a shallow shelf system characterized by high chl-a concentrations in the upper layer $(25 \mathrm{~m})$ associated to a phytoplankton community dominated by large cells $(>10 \mu \mathrm{m})$ where diatoms account for $75 \%$; - an open ocean system characterized by nitrates concentrations in the upper $520 \mathrm{~m}$ ten times lower than over the shelf and a nutricline as well as a SCM 2 to 3 times deeper than over the shelf. Offshore, the chlorophyll biomasses are one order of magnitude lower than over the shelf and associated to small-size phytoplankton $(<5 \mu \mathrm{m})$ mainly prasinophytes and haptophytes. Chl-a biomasses are very low in surface while the highest biomass, 5 to 10 times higher than in surface, are observed in a deep and 10 well-marked SCM located between 20 and $80 \mathrm{~m}$. Results also pointed a variability of biomass and phytoplankton groups inherent to these two Arctic systems in time and space.

\section{Discussion}

Previous studies showed that the distribution of phytoplankton was controlled mainly by 15 environmental forcing, initially by irradiance and then nutrient distribution (Hill and Cota, 2005), two parameters sensitive to recent climate change. The relative importance of different physical mechanisms that could affect the availability of nutrients and light will be investigated in the discussion to explain the observed phytoplankton distributions. The various ice conditions we encountered during the cruise provide precious information to investigate the impact of ice cover on the Arctic ecosystem. The extended ice free area observed for the first time over the western Arctic basins, until $600 \mathrm{~km}$ north of the shelf edge, gives a unique opportunity to compare phytoplankton in ice-covered and ice-free basins.

\section{BGD}

8, 6919-6970, 2011

\section{Phytoplankton distribution in the Western Arctic Ocean \\ P. Coupel et al.}

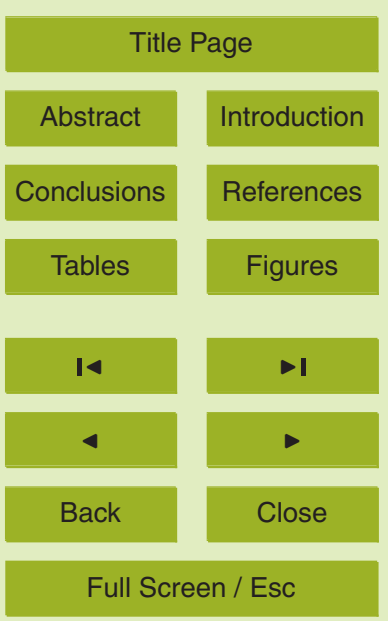

Printer-friendly Version

Interactive Discussion 


\subsection{A comparative study: biomass/productivity and CHEMTAX/Light microscopy}

\subsubsection{CHEMTAX/Light microscopy}

To analyse the reliability of the phytoplankton taxonomy derived from pigments com5 position through CHEMTAX, our pigments biomass determined by HPLC (Fig. 10a and d) are confronted with phytoplankton abundance (Fig. 10b and e) and biomass (Fig. 10c and f) determined from light microscopy by the South Korean group. Both, light microscopy and the CHEMTAX, revealed similar phytoplankton communities composed of Bacillariophyceae (diatoms in the CHEMTAX), Dinophyceae, Cryptophyceae,

10 Chrysophyceae, Prasinophyceae and Prymnesiophyceae (not shown). In addition, Dictyochophyceae was identified by light microscopy while Cyanophyceae and Chlorophyceae, two picoplanktonic groups, are evidenced by the CHEMTAX. For the comparison, phytoplankton was gathered in four different groups according to the size: picoplancton, nanoplancton, diatoms and dinoflagellates (Fig. 10). There is a good relationship between the mass of pigments associated to diatoms by the CHEMTAX and the abundance of diatoms estimated by light microscopy at the SCM $\left(R^{2}=0.97\right.$, Fig. 9a) and at surface $\left(R^{2}=0.79\right.$, not shown). Both methods exhibit the high presence of diatoms over the shelf and its decrease over the basins concomitant with the decrease of the total abundance by a factor two (Fig. 10b) and biomass by a factor five 20 (Fig. 10a and c) offshore. In return, no relation $\left(R^{2}<0.1\right)$ is found between the CHEMTAX outputs and the light microscopy concerning the picoplankton (Fig. 9b) and the nanoplankton (Fig. 9c) indicating a strong variation in the estimation of small-sized phytoplankton according to the method used for the determination. Offshore, picoplankton, although dominating the CHEMTAX assemblages (Fig. 10d) and representing $55 \%$ of bon biomass (Fig. 10f). Nanoplankton accounts for a majority $(\sim 65 \%)$ of the carbon biomass in offshore stations and diatoms and dinoflagellates despite a ten times lower abundance (30 $000 \mathrm{cell}^{-1}$ ) than pico-sized and nano-sized phytoplankton account for
BGD

8, 6919-6970, 2011

\section{Phytoplankton distribution in the Western Arctic Ocean \\ P. Coupel et al.}

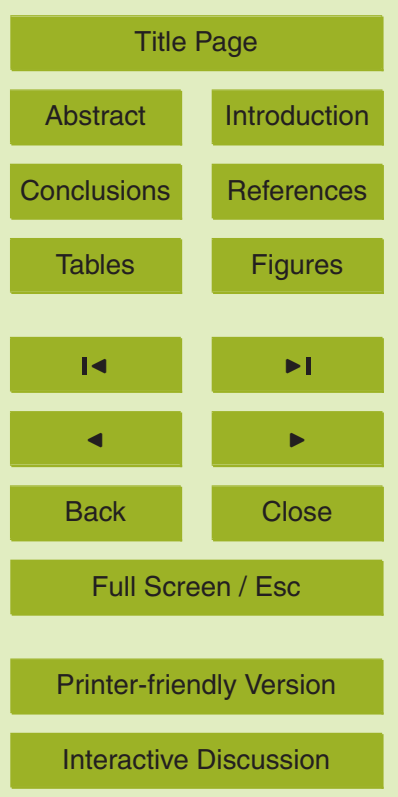

Interactive Discussion 
more than $30 \%$ of the total carbon biomass, especially in the high latitudes covered by ice $\left(>80^{\circ} \mathrm{N}\right)$. These observations highlight that CHEMTAX provides a relatively good approximation of the biomass in the productive area $\left([\mathrm{chl}-\mathrm{a}]>1.00 \mathrm{mg} \mathrm{m}^{-3}\right)$ dominated by diatoms but seems to be a better indicator of cells abundance than biomass in the 5 low productive offshore waters ([chl-a] $\left.<1.00 \mathrm{mg} \mathrm{m}^{-3}\right)$.

The absence of CHEMTAX calibration with phytoplankton from the Arctic Ocean and the overlap of marker pigments between different taxonomic groups could bias the pigments interpretation. Low temperature and the specific light cycle occurring in the polar oceans could result in pigments agency of the polar species far from the temper10 ate and tropical species. A large contribution ( $>75 \%$ ) of unidentified picoplankton and nanoplankton in the low biomass basins does not allow a precise comparison of both, taxonomic and pigments related methods. Indeed, unidentified nanoplankton could include small-sized diatoms largely observed over the basins after some recounting by optical microscopy. The results presented here highlight the complementarity of

Here we would like to investigate whether the chlorophyll biomass is a good index of the primary production. Collocated comparisons are made between chl-a biomass estimated by HPLC and primary production measured by the South Korean group (Table 2, Lee et al., 2011a).

25 The averaged carbon uptake rates of phytoplankton in the euphotic depth were $2.00 \mathrm{mgC} \mathrm{m}^{-3} \mathrm{~h}^{-1}$ in shelf waters and $0.05 \mathrm{mgC} \mathrm{m}^{-3} \mathrm{~h}^{-1}$ over the basins. For the

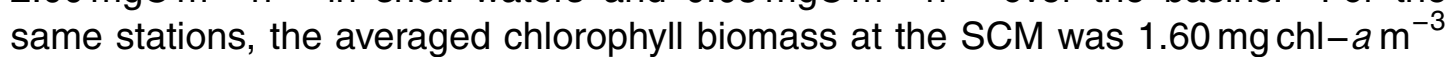
and $0.40 \mathrm{mg} \mathrm{chl}-\mathrm{am}^{-3}$ in shelf and basins respectively. It suggests that primary 6936
BGD

8, 6919-6970, 2011

\section{Phytoplankton distribution in the Western Arctic Ocean \\ P. Coupel et al.}

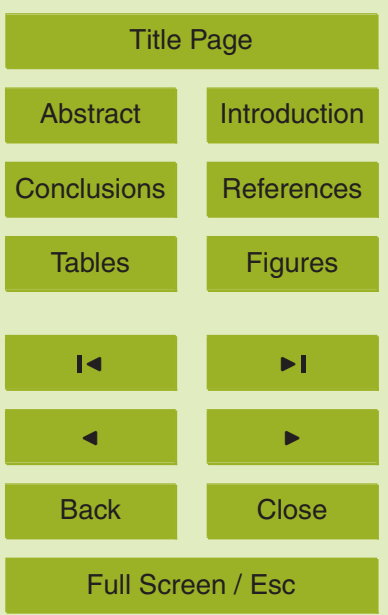

Printer-friendly Version

Interactive Discussion 
production (PP) was 40 times higher over the shelf than over the basins while chlorophyll biomass over the shelf was only 10 and 4 times higher than offshore in surface and sub-surface respectively. It means that for an equivalent chl-a biomass, communities over the shelf are 4 to 10 times more productive in term of carbon production 5 than over the basins. This observation suggests that the PP does not depend only on the chlorophyll biomass variability. Indeed at most of the stations, the maximum of PP was not coinciding with the SCM but was detected at shallower depths. Calculation of a productivity ratio (PP/Chl-a) shows the strong influence of the irradiance level on the Arctic phytoplankton productivity (Fig. 9d). The highest productivity ratios are mea10 sured for irradiance equal to $50 \%$ of the surface value. Such irradiance was achieved around $5 \mathrm{~m}$ in the shelf waters and $20 \mathrm{~m}$ in the clear waters of Canadian Basin. In contrast, too high or too low irradiance strongly reduces the productivity. Thus, species growing under irradiance equal to $100 \%$ or lower than $30 \%$ showed productivity one orders of magnitude lower than for $50 \%$ irradiance. When irradiance was under $10 \%$

\section{$50 \%$ of irradiance.}

The lowest PP $\left(0.01 \mathrm{mgC} \mathrm{m}^{-3} \mathrm{~h}^{-1}\right)$ are measured in the ice-free $\mathrm{CB}$ and heavy ice covered areas (ice cover $>70 \%$ ) where the decoupling between the maximum of productivity $(\sim 10 \mathrm{~m})$ and the SCM $(\sim 50 \mathrm{~m})$ is well marked. At the depth of the SCM, the very low light penetration ( $<10 \%$ of surface light) reduces the primary production to negligible rates. The maximum PP, measured in the well-illuminated surface waters, remains low $\left(\sim 0.01 \mathrm{mgC} \mathrm{m}^{-3} \mathrm{~h}^{-1}\right)$ due to very low chl-a levels prevailing in these surface waters $\left(<0.05 \mathrm{mg} \mathrm{chl}-\mathrm{a} \mathrm{m}^{-3}\right)$. In conclusion, the deep SCM observed in ice-free basins and heavy-ice covered basins does not constitute a productivity maximum, but results mainly from an increase in the chl-a to $C$ ratio and represents slow-growing communities with a small contribution to total integrated productivity. In the AMZ the shallower SCM $(25 \mathrm{~m})$ is associated to higher irradiance and coincides with the maximum of PP. The productivity has increased by a factor five $\left(0.08 \mathrm{mgC} \mathrm{m}^{-3} \mathrm{~h}^{-1}\right)$ as compared to the ice-free areas despite similar chlorophyll biomass. Over the shelf,
BGD

8, 6919-6970, 2011

\section{Phytoplankton distribution in the Western Arctic Ocean \\ P. Coupel et al.}

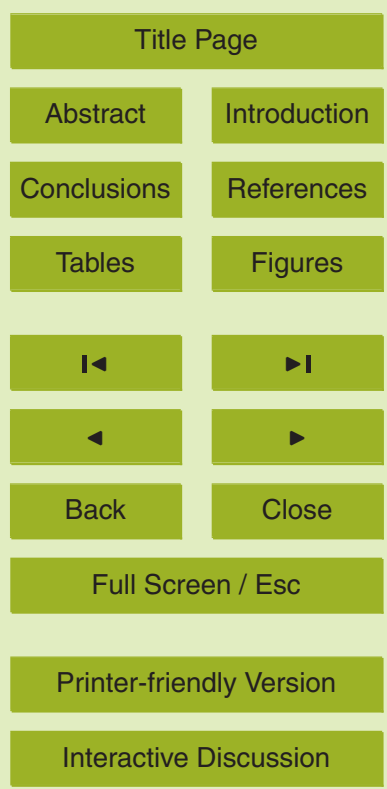


most of the biomass was measured in the upper $20 \mathrm{~m}$ where chlorophyll is concentrated $\left(0.50\right.$ to $\left.5.00 \mathrm{mg} \mathrm{chl}-\mathrm{a} \mathrm{m}^{-3}\right)$ and results in high primary production rates $(1.00$ to $20.00 \mathrm{mgC} \mathrm{m}^{-3} \mathrm{~h}^{-1}$ ). The productivity ratio (PP/Chl-a) is high and implies that shelf phytoplankton produces a large amount of organic carbon.

5 The depth of the SCM was a crucial parameter to investigate the degree of activity of the Arctic community and its efficiency to drawdown carbon and export it. The nearsurface communities seem to be more active and productive leading to a more efficient carbon uptake compared to deep SCM in ice-free basins composed of slow-growing species.

\subsection{Spatial variability of phytoplankton}

\subsubsection{A shallow productive shelf $\left(66^{\circ} \mathrm{N}-73^{\circ} \mathrm{N}\right)$}

Over the Chukchi shelf, the continuous lateral input of nutrient-rich PW from Bering Strait and the nutrients regeneration from shallow sediments $(<50 \mathrm{~m})$ are associated to high nutrients $\left(\mathrm{NO}_{3}=5-10 \mu \mathrm{M}\right.$, Fig. 11e) in the euphotic depth and high chl-a biomass

15 ( $1 \mathrm{mg} \mathrm{chl}-\mathrm{a} \mathrm{m}^{3}$, Fig. 11g). The nutrient-rich waters favour large-sized phytoplankton $(>10 \mu \mathrm{m})$ especially diatoms, the more opportunist taxa to take advantage of high nutrient concentration (Gradinger and Baumann, 1991). These conditions are characteristic of new production together with efficient transfer to the upper trophic level and important carbon export to the shallow seafloor (Parsons et al., 1984; Jeffrey and Vesk, 20 1997).

The establishment of a thin SFL $(S<31$, Fig. 11a) in the north part of the shelf $\left(>70^{\circ} \mathrm{N}\right)$ through meltwater inputs inhibits the replenishment in nitrate of surface waters $\left(\mathrm{NO}_{3}<1 \mu \mathrm{M}\right.$, Fig. 11e). The nutricline and the SCM were observed the interface between the basis of the SFL and the upper limit of the PW, i.e. between both isohalines 31 and 32 (Fig. 11a). In the southern part of the shelf, the flow of PSW through

\section{BGD}

8, 6919-6970, 2011

\section{Phytoplankton distribution in the Western Arctic Ocean \\ P. Coupel et al.}

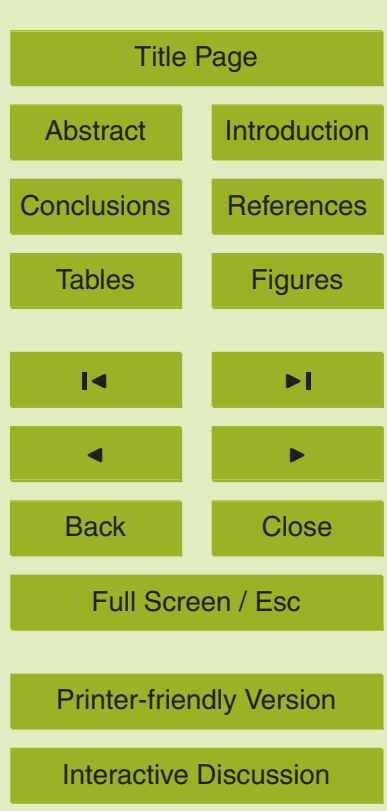

6938 
Bering Strait (Fig. 11b) impeded the establishment of the SFL and high surface chl-a concentrations could be sustained.

The peak of biomass $\left(5 \mathrm{mg} \mathrm{chl}-\mathrm{a} \mathrm{m}^{-3}\right)$ located at Central Canyon $\left(73^{\circ} \mathrm{N}\right)$ was linked to the ice edge (ice cover $=40 \%$ ) and to a shallow and large nutrient reservoir (Fig. 11e 5 and f) probably identified as the Chukchi-Beaufort shelf-break jet (BSJ, Fig. 1a) according to Pickart (2004). Waters with nitrate concentrations as high as $10 \mu \mathrm{M}$ at $10 \mathrm{~m}$ were submitted to high irradiance following the recent ice shrinking and led to a typical Arctic spring phytoplankton bloom. Moreover, the interaction between the BSJ and the northward flow of PWW created turbulence and upwelling of the subsurface nutrient 10 rich-waters increasing the nutrient concentration in the upper layers. Upwelling is highlighted by the upward depression of the isohaline and isotherm at $73^{\circ} \mathrm{N}$ (Fig. 11b) and by the high silicate concentrations in surface ( 20 $\mu \mathrm{M}$, Fig. 11f).

Regions of low chl-a concentrations $\left(0.2 \mathrm{mg} \mathrm{chl}-\mathrm{a} \mathrm{m}^{-3}\right.$, Fig. $\left.11 \mathrm{~g}\right)$ like measured near Point Hope $\left(69^{\circ} \mathrm{N}\right)$ could be linked to the circulation of the buoyant ACC $(S<32.5$, 15 Fig. 1a), a coastal branch of the PSW carrying warm $\left(T^{\circ}>4^{\circ} \mathrm{C}\right)$ and nutrient-depleted waters $\left(\mathrm{NO}_{3}=0.001-0.1 \mu \mathrm{M}, \mathrm{Si}<5 \mu \mathrm{M}\right.$, Fig. 11e and f) along the Alaskan coast. In these coastal waters, the relative abundance of small-sized phytoplankton groups (Cryptophytes, Prasinophytes, Chrysophytes, Cyanobacteria) adapted to low nutrient concentration increased although diatoms still dominate the phytoplankton assemblages (40\%, Fig. 8$)$.

The elevated sub-surface chl-a concentrations of $1.5 \mathrm{mg} \mathrm{chl}-\mathrm{a} \mathrm{m}^{-3}$ measured on the outer shelf around $40 \mathrm{~m}$ depth in the extension of the Central and Barrow canyon (Stations R17 and S24, Fig. 6b) could be fuelled by nutrients rich waters plumes channelled by the canyons. Central Canyon and Barrow Canyon represent major ways to channel the Pacific waters toward the open Arctic (Coachman et al., 1975; Weingartner et al., 2005) and the generations of eddies are commonly observed due to the baroclinic instability of PWW flowing offshore (Pickart et al., 2005). However, the CHINARE 2008 data are too sparse to highlight these mesoscale eddies ( $\sim 10 \mathrm{~km}$ radius). The outer shelf SCM were dominated by Prymnesiophytes and Prasinophytes (Fig. 8), both

BGD

8, 6919-6970, 2011

\section{Phytoplankton distribution in the Western Arctic Ocean \\ P. Coupel et al.}

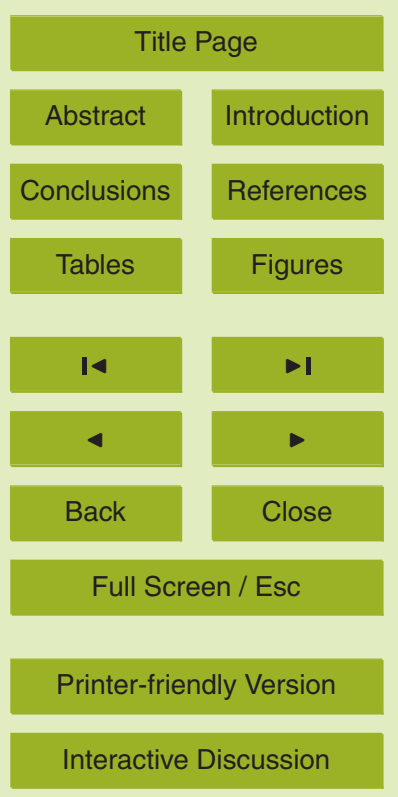

Interactive Discussion 
groups adapted to feed on regenerated matter brought up by turbulent processes. Moving northward, the PWW finally sink deeper by density and carry their nutrient contents at greater depths (Fig. 11b).

\subsubsection{Open ocean variability}

5 Preconditioning of nutrient source

Offshore, the major nutrients source consists in the subsurface reservoir of the PW, especially the PWW centered on the silicate maximum (Fig. 12c). Because of great depths, there is no enrichment of surface layers by sediments. Concerning riverine inputs as a nutrient source, although the McKenzie river bring large amount of fresh10 waters in the Canadian Basin (Jones et al., 2008), it seems to have no impact on the upper layer nutrient contents. The McKenzie river end-members were characterized by a phosphate depletion $\left(\mathrm{NO}_{3}=10 \mu \mathrm{M} ; \mathrm{PO}_{4}=0 \mu \mathrm{M}, \mathrm{Si}=65 \mu \mathrm{M}\right.$, Carmack et al., 2004) implying a high N/P ratio whereas the upper layers of the open WA present low N/P ratio around 6:1, characteristic of the PW end-members. Phytoplankton de15 velopment in spring and summer over the Arctic deep basins could be dependent to the nutrient concentrations in the surface layer before the growing season. Efficiency of the surface layer replenishment with nutrient-rich deep waters during winter is set by the relationship between the depth of the subsurface reservoir of nutrients and the vertical mixing occurring during fall and winter (McLaughlin and Carmack, 2010). If the layer entrained by the winter mixing reaches the depth of the subsurface nutrient reservoir, nutrient-rich waters could be uplifted in surface and relatively high nutrient concentrations could be available for phytoplankton next summer. In contrast, if winter mixing does not reach the nutrient reservoir, only nutrient poor waters will be entrained resulting in low nutrient levels in surface.

25 The depth of the sub-surface nutrient reservoir over the Arctic basins varies zonally. The near-freezing temperature and high silicate concentrations, representative of the PWW core, were observed between $100 \mathrm{~m}$ and $200 \mathrm{~m}$ in the CB and between $50 \mathrm{~m}$
BGD

8, 6919-6970, 2011

\section{Phytoplankton distribution in the Western Arctic Ocean \\ P. Coupel et al.}

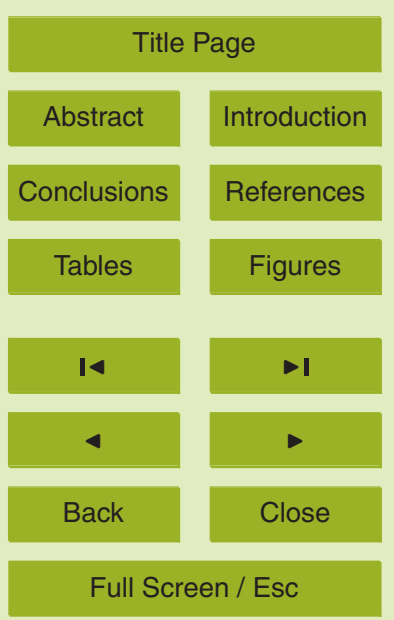

Printer-friendly Version

Interactive Discussion 
and $200 \mathrm{~m}$ in the Chukchi Borderland (Fig. 12b and c). This results in a nutrient reservoir lying $50 \mathrm{~m}$ to $100 \mathrm{~m}$ deeper in the CB than in the Chukchi Borderland leading to nitrate concentrations in the euphotic layer three times higher in the west than in the east (Fig. 5c). The depth of the Pacific reservoir was forced by the Ekman transport 5 related to the BG circulation but also by the buoyancy (i.e. salinity) of the PW flowing in the open Arctic (Fig. 12a). The depression of the isohalines in the center of the $B G\left(74^{\circ} \mathrm{N}\right)$ resulted of the convergence of freshwater through the anticyclonic circulation. The isohaline 32.5 associated to the upper layer of the PWW was observed $50 \mathrm{~m}$ deeper in the center of the gyre than in the rest of the CB (Fig. 12a). Moreover, the 10 gyre circulation supplies "fresher" PWW in the Chukchi Borderland than in the Canadian Basin. The PWW flowing west through the Central Canyon was localized between the 32 and 33.5 isohalines while the waters branch flowing east through the Barrow Canyon was observed between the 32.5 and 33.5 isohalines. The higher buoyancy of the PWW spreading west has been previously explained by the contribution of a new 15 type of waters (Nishino et al., 2008). This new-type of waters is near freezing point $\left(<-1.4^{\circ} \mathrm{C}\right)$, enriched in nutrients but fresher $(S=32)$ than the typical salinity $(S \sim 33)$ caused by spreading of near-freezing PWW in the deep Arctic. These "fresher" PWW are described by Nishino et al. (2008) as summer shelf waters, largely influenced by sea ice melting in the CS, subsequently modified by winter convection on its way to the Chukchi Borderland. In contrast, east of the Chukchi shelf, the circulation displays warm and relatively nutrient poor PSW $\left(\mathrm{NO}_{3}<5 \mu \mathrm{M}\right)$ that has flowed along the Alaskan coast in summer (Coachman and Barnes, 1961; Shimada et al., 2001) and lies above the typical PWW in the Canadian Basin. The PSW identified by a sub-surface temperature maximum $\left(>-1^{\circ} \mathrm{C}\right)$ occurring at $S<32$ was identified in the south of the $\mathrm{CB}$ between latitude $72^{\circ} \mathrm{N}$ and $78^{\circ} \mathrm{N}$ (Fig. 12b). A deeper nutrient reservoir in the CB implies that winter nutrient replenishment would be reduced as compared to a shallow nutrient reservoir.

Because of absence of wind stress in winter due to ice cover, cooling and associated ice formation were the only processes able to disrupt the stratification and enhance
BGD

8, 6919-6970, 2011

\section{Phytoplankton distribution in the Western Arctic Ocean \\ P. Coupel et al.}

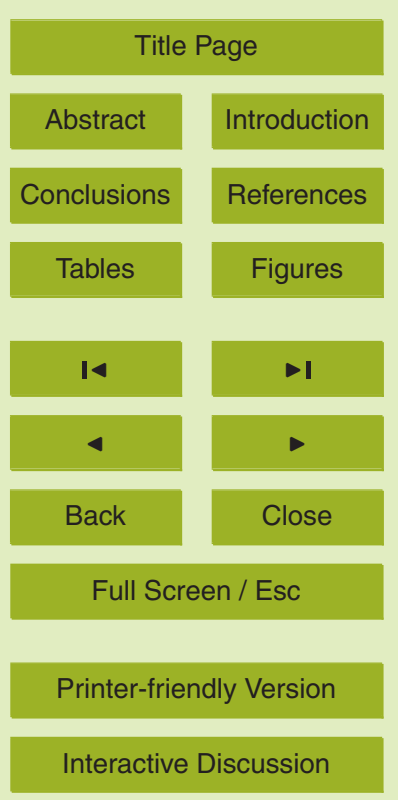


mixing of the underlying layers. The winter sea-ice formation and growth are known to be associated to brine rejection and deepening of the mixed layer through haline convection (Aagaard et al., 1981). The more sea-ice was formed in winter and melted in summer, the more haline convection will be efficient. Ice free conditions at the end 5 of summer 2007 would accelerate the heat transfer at air-sea interface conducting to important sea-ice formation during winter 2007-2008. At the opposite, the multi-year ice area north of $83^{\circ} \mathrm{N}$ is covered by ice even in summer reducing ice formation in winter. However, observations during recent winters (2004-2009) have shown that the winter mixed layer never exceeded $40 \mathrm{~m}$ in the CB (Toole et al., 2010) despite ice free 10 conditions in summer since 2006. The great depth of the nutrient reservoir combined with a weak winter mixing suggests that the surface layer of the CB would be deficient in nutrients even before the growing season as compared to conditions in the Chukchi Borderland.

\section{Interplay of stratification and freshwater content (SFL) of the upper layer controlled the variability of phytoplankton in surface and at the SCM} 15

Surface waters in the open Arctic are oligotrophic $\left(\sim 0.05 \mathrm{mg} \mathrm{chl}^{-} \mathrm{am}^{-3}\right.$, Fig. $\left.12 \mathrm{~g}\right)$ and pigments suggest dominance of fucoxanthin (37\%) ordinary associated to diatoms (Fig. 8). These diatoms could correspond to sub-ice algae, released in surface waters by ice melting or diatoms adapted to low salinity (25 to 29) and low nutrient condi20 tions $\left(\mathrm{NO}_{3}<0.2 \mu \mathrm{M}\right.$, Fig. 12e) prevailing in surface. Massive accumulations of centric diatoms $M$. artica under the ice have been previously highlighted in the western Arctic (Melnikov and Bondarchuk, 1987; Gosselin et al., 1997) and could explain the diatom presence observed near the surface. The low phytoplankton biomass of open Arctic surface waters during summer 2008 could be attributed to nutrient depletion $25\left(\mathrm{NO}_{3}<0.2 \mu \mathrm{M}, \mathrm{Si} \sim 1.0 \mu \mathrm{M}\right.$, Fig. $\left.12 \mathrm{e}\right)$ throughout the low salinity surface layer $(S<30)$. The depletion is due to the combined action of the in situ production which consumes nutrients and the strong stratification which inhibits the replenishment of surface waters by vertical exchange. Increase of the chlorophyll biomass in the AMZ is linked to a

\section{BGD}

8, 6919-6970, 2011

\section{Phytoplankton distribution in the Western Arctic Ocean \\ P. Coupel et al.}

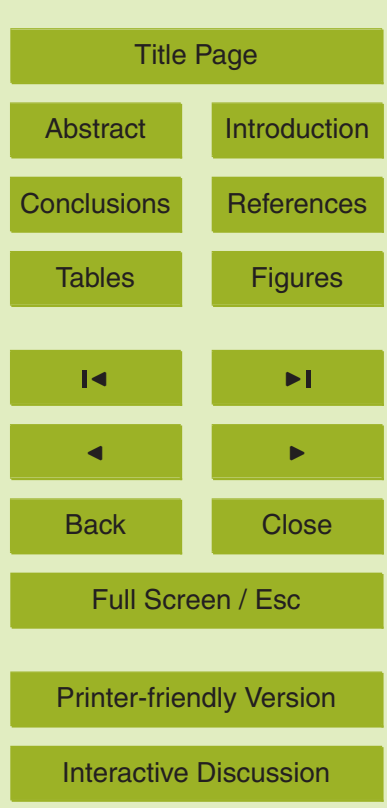


lower stratification ( $\mathrm{SI}=2$, Fig. 4d) attributed to less freshwater accumulation. Furthermore, a rapid decrease of the ice coverage from more than $90 \%$ to $50 \%$ in only a few days (Figs. $2 \mathrm{~b}$ and $\mathrm{c}, 6 \mathrm{a}$ ) could explain why nutrients are still in enough concentration $\left(\mathrm{NO}_{3}=0.4 \mu \mathrm{M}, \mathrm{Si} \sim 4.0 \mu \mathrm{M}\right.$, Fig. $12 \mathrm{c}$ and $\left.\mathrm{e}\right)$ in the upper layers of the $\mathrm{AMZ}$ promoting 5 relatively high biomass.

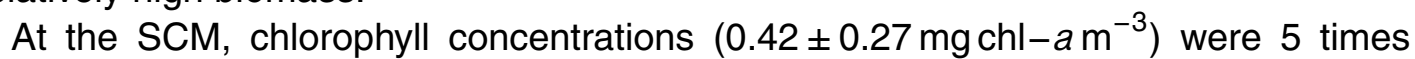
higher than in surface due to the proximity with the nutrient reservoir and sufficient light levels to sustain relatively high chlorophyll concentrations. Because of a strongly reduced ice cover and thin first-year ice over most of the basins, the light penetra10 tion was relatively high $(\sim 60 \mathrm{~m})$. The three stations covered by multi-year ice $\left(>84^{\circ} \mathrm{N}\right)$ exhibit the lowest SCM concentrations $\left(0.15 \pm 0.11 \mathrm{mg} \mathrm{chl}^{-a \mathrm{~m}^{-3}}\right.$, Fig. $\left.12 \mathrm{~g}\right)$. The euphotic depth evaluated at $50 \mathrm{~m}$ was shallower than the nutricline depth $(60 \mathrm{~m})$ forcing phytoplankton to develop in highly depleted nutrient waters.

In the AMZ, increased light penetration together with a shallow nutricline (20$1540 \mathrm{~m})$ and implementation of the stratification sustained elevated chl-a biomass $\left(0.55 \pm 0.20 \mathrm{mg} \mathrm{chl}-\mathrm{a} \mathrm{m}^{-3}\right)$. The partially ice covered area sampled in August in the $\mathrm{CB}\left(78^{\circ} \mathrm{N}\right.$ to $\left.82^{\circ} \mathrm{N}\right)$ was associated to the northern edge of the BG characterized by a rebound of the pycnocline. The rebound of the pycnocline implies an upwelling of nutrients in the well-lit layers and results in a shallow nutricline and SCM (40 m, Fig. 12g) as compared with the deep nutricline and SCM $(>60 \mathrm{~m})$ observed in the ice free and heavy ice part of the CB.

The AMZ observed over the MAP and the north of the CC in September (stations N83 to P31) was associated to a shallow nutrient reservoir $(20 \mathrm{~m})$ and a weak freshwater accumulation (SFL 20 m). High nutrient concentrations were available in optimal light conditions and the productivity increased by a factor 5 to $10\left(\mathrm{PP} \sim 0.1 \mathrm{mgC} \mathrm{m}^{-3} \mathrm{~h}^{-1}\right.$ ) as compared to CB. Prasinophytes, typically the dominant groups at surface over the basins (Hill et al., 2005), were promoted over Haptophytes in the AMZ (Fig. 8).

Chl-a concentrations are highly variable in the ice-free basins where the nutricline is the deepest $(40-70 \mathrm{~m})$. Nutrients have been depleted (Fig. 12e) by phytoplankton

\section{BGD}

8, 6919-6970, 2011

\section{Phytoplankton distribution in the Western Arctic Ocean \\ P. Coupel et al.}

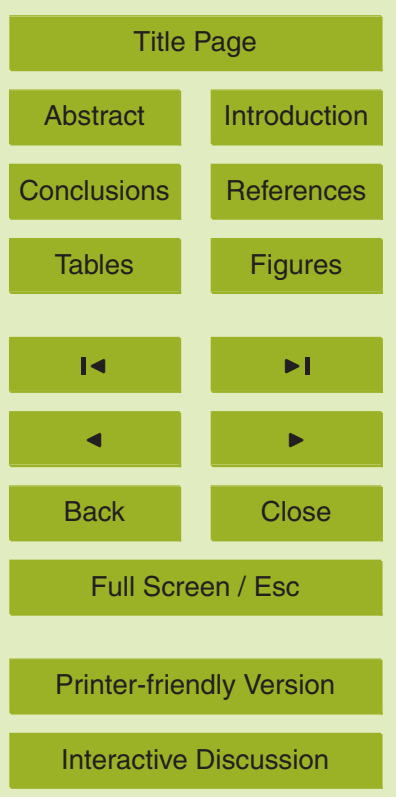


activity in the euphotic layer as the result of 10 to 30 days of ice-free conditions (Fig. 2c). The SCM are observed at the basis of the SFL and would control the nutricline depth acting as a barrier inhibiting uplift of nutrients. The anticyclonic circulation of the BG centered in the south of the CB accumulated large volume of freshwaters from McKen-

5 zie river and meltwater (Proshutinski et al., 2002, Jones et al., 2008) and resulted in a thick SFL $(80 \mathrm{~m})$ and a high stratification index $(\mathrm{SI}>6$, Fig. $4 \mathrm{~d})$ in agreement with the area of highest liquid freshwater (LFW) content calculated by Rabe et al. (2011). The nutricline and the SCM were deep and dominated by Cryptophyes, a Haptophytes subdivision well-adapted to grow at low irradiance (Clay et al., 1999). The very low 10 primary production rates $\left(0.009 \pm 0.001 \mathrm{mgC} \mathrm{m}^{-3} \mathrm{~h}^{-1}\right.$, Table 2) associated to stations with a deep SCM reflected slow growing population with very high $\mathrm{Chl}-\mathrm{a} / \mathrm{C}$ ratio suggesting low carbon uptake. The deepening of the nutricline and of the SCM observed in the ice-free area was in agreement with recent findings in the CB indicating a $20 \mathrm{~m}$ deepening of the SCM between 2003 and 2008 (Mc Laughlin and Carmack, 2010).

15 The productivity of the SCM decreases when the SCM deepens and haptophytes are favoured over prasinophytes. The low productivity and carbon uptake of these communities are consistent with the observations of Cai et al. (2010) on a decrease of the carbon sink over the ice-free basins.

In conclusion, the SFL by setting the depth of the nutricline, plays a key role in controlling biomass, productivity and phytoplankton communities at the SCM. The depth of the SCM is modulated by sea-ice melting and inflow of rivers through the thickness of the SFL. The thin SFL observed in the AMZ conducts to the highest primary production $\left(0.300 \mathrm{mgC} \mathrm{m}^{-3}\right.$ at $\left.79^{\circ} \mathrm{N}\right)$ dominated by diatoms and haptophytes in biomass. In contrast, in the ice-free basins, nutrients were depleted and the nutricline was deepened by the freshwater accumulation in the upper layer. Low light conditions at the SCM imply development of unproductive phytoplankton assemblages with low carbon production. The SFL also interplays with the surface communities by determining the distance between the surface and the subsurface reservoir. Effects of the SFL must be coupled with the stratification and Arctic halocline changes to understand the vertical

BGD

8, 6919-6970, 2011

\section{Phytoplankton distribution in the Western Arctic Ocean \\ P. Coupel et al.}

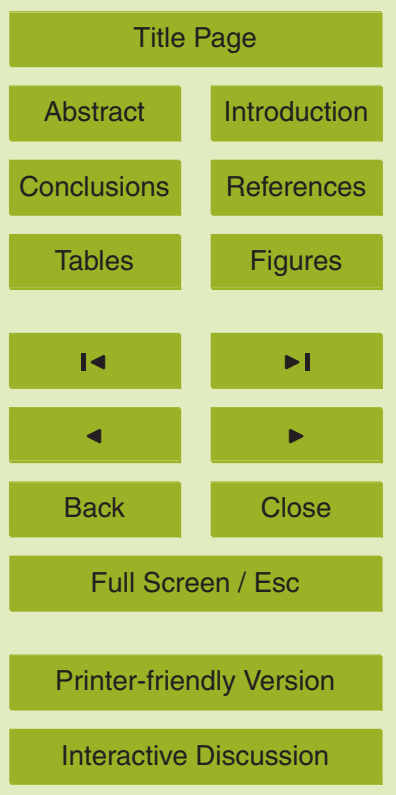

Interactive Discussion 
exchange efficiency while the depth of the Pacific reservoir inform on the pool of nutrients available for the upper layer. Association of a deep nutrient reservoir, a large SFL and a strong stratification in the ice-free CB resulted in the lowest surface chlorophyll-a concentrations.

\section{4.3 Comparison with previous expeditions in the Western Arctic}

The regions investigated during the CHINARE 2008 cruise have been poorly documented before especially the Arctic basins where heavy ice conditions limit the progression and hamper the deployment of underwater instruments. The most studied areas were the Chukchi shelf (Hameedi et al., 1978), the shelf break and slope area (Hill 1 and Cota, 2005; Sukhanova et al., 2009). Only one cruise carried out in 1994 (AOS) provides information about phytoplankton communities in the WA for latitudes as high as $90^{\circ} \mathrm{N}$ despite a heavy ice cover higher than $80 \%$ between $75^{\circ} \mathrm{N}$ and $90^{\circ} \mathrm{N}$ (Booth and Horner, 1997; Gosselin et al., 1997). A drastic decrease of the average surface phytoplankton abundance was observed in the Chukchi Borderland and the MAP from $154970 \mathrm{cellI}^{-1}$ in August 1994 to $504 \mathrm{celll}^{-1}$ in August 2008. The high abundance in 1994 was attributed to the dominance of picoplankton $(<2 \mu \mathrm{m}), 10$ to 20 times more concentrated than in 2008. However, phytoplankton biomass is the same order of magnitude between $2008\left(10.81 \mathrm{mgC} \mathrm{m}^{-3}\right)$ and $1994\left(11.44 \mathrm{mgC} \mathrm{m}^{-3}\right)$. This drastic decrease of the abundance despite an unchanged biomass could be explained by an 20 increase of the biomass per cell. It can be attributed to an increase of the contribution of nanoplankton $(+70 \%)$ and diatoms $(+5 \%)$ in the total biomass while picoplankton biomass has decreased $(-50 \%)$. The drastic reduction of the ice cover from $95 \pm 4 \%$ in 1994 to $40 \pm 36 \%$ in 2008 allowed the apparition of an AMZ between $78^{\circ} \mathrm{N}$ and $82^{\circ} \mathrm{N}$ in 2008 (Fig. 2b) while the area was largely covered by heavy ice in 1994 . The

formation of an extended AMZ in 2008 drives a fast growth of small (nanoplankton) and large (diatoms) phytoplankton and produces a high carbon biomass increase. Li et al. (2009) also reported a total phytoplankton biomass unchanged between 2004
BGD

8, 6919-6970, 2011

\section{Phytoplankton distribution in the Western Arctic Ocean \\ P. Coupel et al.}

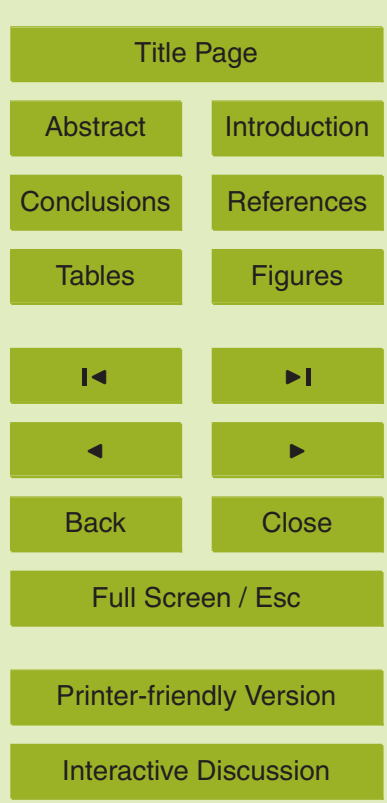


and 2008; however their study highlights a reduction of the nanophytoplankton over the Canadian Basins while picophytoplankton increased.

Community changes were also noted near Barrow Canyon between 2002 and 2008. Barrow Canyon was ice covered (>80\%) in August 2002 and completely ice-free in 5 2008. In 2002, outer shelf surface waters were dominated by Pras and Chl- $b$, two characteristics pigments of picoplankton while at the SCM, the relative abundance of Fuco, representative of diatoms, was two to three times higher than in surface (Hill et al., 2005). This result was in contrast with observations from CHINARE 2008 showing dominance of diatoms in surface (Fuco $\sim 50 \%$ ) while haptophytes (19HF + $19 \mathrm{BF} \mathrm{\sim}$ $1040 \%$ ) and picoplankton (Chl- $b \sim 30 \%$ ) dominated at the SCM. Ice retreat prevailing in 2008 seems to advantage haptophytes communities at SCM while high irradiance in surface could favors diatoms.

Observations over the Chukchi shelf are in accordance with previous investigation highlighting high biomass (Hameedi, 1978; Booth and Horner, 1997) and a diatom dominated ecosystem (Hill et al., 2005; Shukanova et al., 2009). Nevertheless, chl-a concentrations at the ice edge $\left(73^{\circ} \mathrm{N}\right)$ were lower than concentrations expected during typical spring bloom over the Chukchi shelf. In fact, along this extended shelf, biomass as high than 10 to $40 \mathrm{mg} \mathrm{chl}-\mathrm{a} \mathrm{m}^{-3}$ has been already evidenced (Hameedi et al., 1978; Hill and Cota, 2005). Lower chl-a values measured in August 2008 could be linked to early ice retreat over the shelf resulting in post-bloom conditions, underlined by the warming and nutrient depletion of surface waters observed in early August.

\section{Conclusions}

Sea ice melt in the Arctic Ocean has increased steadily since recent decades with acceleration over the last four years. Summer 2008 was a period of exceptional ice retreat enabling a high resolution physical, chemical and biological survey, CHINARE 2008, to be carried out across the Canadian Basin in the western Arctic Ocean up to $86^{\circ} \mathrm{N}$. A strong divide between the shelf and open ocean waters was noted in terms of species

BGD

8, 6919-6970, 2011

\section{Phytoplankton distribution in the Western Arctic Ocean \\ P. Coupel et al.}

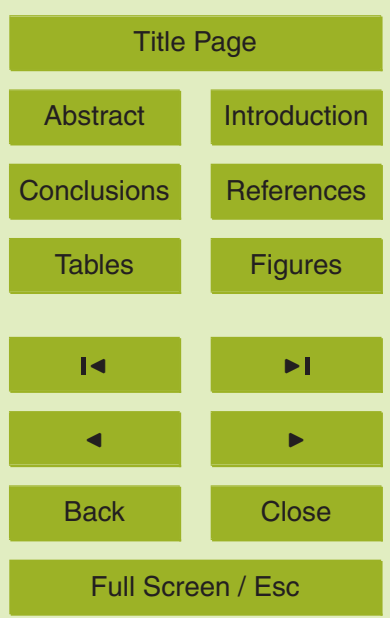

Printer-friendly Version

Interactive Discussion 
composition, abundance, biomass and primary productivity (PP). In the open basins, primary production and biomass were markedly lower and dominated by nano- and pico-sized phytoplankton, mainly haptophytes and prasinophytes. Moreover a subsurface chlorophyll maximum (SCM) was found and is related to the Pacific Waters (PW)

5 subsurface circulation providing the unique source of nutrients. In ice free basins, ice melting strengthens the surface freshwater layer (SFL) which deepens either the nutricline and the SCM. These areas are dominated by small diatoms in the surface layers while slow-growing haptophytes using regenerated nutrients but producing low carbon prevail at SCM outcompeting pico-sized phytoplankton in the algal assemblages. The 10 setting of the SFL through ice melting leads the upper layers of the CB to oligotrophy by removing the nutrients source and preventing any fuelling from the subsurface pool of nutrients towards the surface. However, despite a maximum chlorophyll biomass in sub-surface, the maxima of PP mainly due to nanoplankton occurred in the very stratified and well-lit surface layers. At the opposite, a fine SFL linked to recent ice melting 15 could drive to an extended AMZ where phytoplankton grows fast and consumes the available nutrients.

In contrast, Arctic shelves sustained by the continuous flow of nutrients-rich PW through the Bering Strait and by nutrient regeneration from the shallow sediments were rich and dominated by diatoms. Early August 2008, an ice-edge bloom is observed north of the shelf $\left(73^{\circ} \mathrm{N}\right)$ associated to diatoms and haptophytes blooming species. Over the shelf, two effects associated to the lengthening of the ice-free season could rapidly limit the phytoplankton production after the spring bloom. After nutrients depletion in surface, a strengthening of the stratification by surface freshening could decrease the replenishment with deep nutrients even over the shelves. The warming of the shelf waters could promotes zooplankton and microbial loops and thus reduce the phytoplankton population through predation pressure. The assumption of an increase of the primary production relative to a longer ice-free period needs to consider the probable decrease of phytoplankton standing stock and production with time.

BGD

8, 6919-6970, 2011

\section{Phytoplankton distribution in the Western Arctic Ocean \\ P. Coupel et al.}

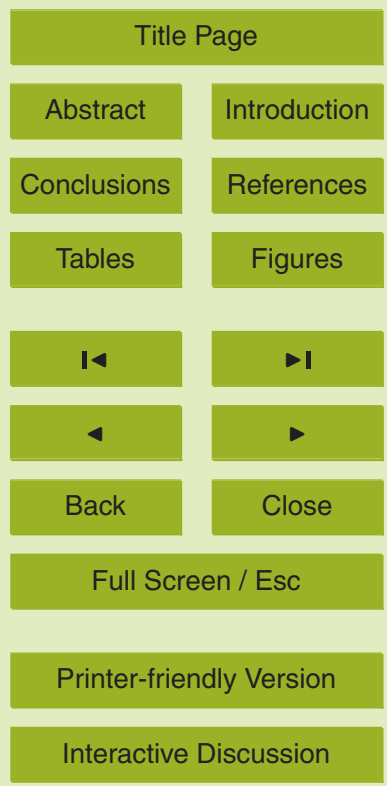


Very few historical in situ data documented previously the western Arctic zone pointing out the difficulties to establish a trend of phytoplanktonic evolution over time. Compared to an earlier underway survey in 1994, one can witness in the Borderland area a drastic decrease of total phytoplankton abundance due to much lower pico-sized phytoplankton. However in the AMZ (Arctic Melting Zone) at $78^{\circ} \mathrm{N}$ to $82^{\circ} \mathrm{N}$, carbon biomass and chlorophyll-a content have increased by a factor 10 as compared with conditions when areas were ice-covered. This biomass increase is linked to the appearance of diatoms and large flagellates in these favourable hot spots. Although satellite observations predicted that primary productivity and phytoplankton biomass may increase 10 in the Arctic Ocean as a result of sea ice melt, this does not seem to be the 2008 scenario in the Western Arctic. With ice retreat, light limitation in the basins seems to be replaced by nutrient limitation which ultimately will impact on PP. Severe nutrient depletion down to $80 \mathrm{~m}$ associated to weak winter ventilation might lead to a quite unproductive Canadian Basin in a close future. In situ observations of the primary producers along the Arctic during the ice decline year provided us evidences of the impact of global climate changes along the entire food chain and the carbon biological pump.

Acknowledgements. This research is a contribution to the Arctic Tipping Points (ATP) project (http://www.eu-atp.org) funded by FP7 of the European Union (contract \#226248) and the European program DAMOCLES (Developing Arctic Modeling and Observing Capabilities for Longterm Environmental Studies, 2007-2010). We thank the captain and the crew of the Xuelong icebreaker for the opportunity to take part in the field work in the Arctic Ocean. We thank the Second Institute of Oceanography (SOA, Hangzhou) to invite the French scientists from the LOCEAN laboratory (UPMC-University Pierre et Marie Curie) to participate to the CHINARE cruise. We are grateful to SOA to support the stay of French scientist in their laboratory and 25 the pigment analysis (by HPLC) but also for their warm welcome and helpfulness. We thank S. Q. Gao and Y. Lu for their contributions for nutrients analysis and sample collections as well as professor J. P. Zhao and the physical Chinese and Finnish teams for the acquisition and transfer of the hydrological data (CTD). Philippe Lattes is warmly thanked for his help in the creation of several computer programs to interpret the data.
BGD

8, 6919-6970, 2011

\section{Phytoplankton distribution in the Western Arctic Ocean}

P. Coupel et al.

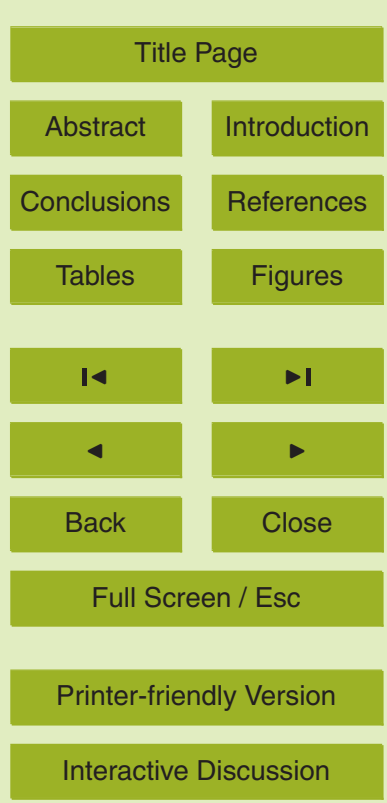


The publication of this article is financed by CNRS-INSU.

\section{References}

Aagaard, K. and Roach, A. T.: Arctic Ocean-shelf exchange: measurements in Barrow Canyon, 5

Aagaard, K., Coachman, L. K., and Carmack, E.: On the halocline of the Arctic Ocean, Deep Sea Res. I, 28, 529-545, 1981.

ACIA: Arctic Climate Impact Assessment. Cambridge University Press, Cambridge, available at: http://www.acia.uaf.edu (last access: 2 June 2011), 2005.

10 Ahlnäs, K. and Garrison, G. R.: Satellite and oceanographic observations of the warm coastal current in the Chukchi Sea, Arctic, 37, 244-254, 1984.

Arrigo, K. R., van Dijken, G., and Pabi, S.: Impact of a shrinking Arctic ice cover on marine primary production, Geophys. Res. Lett., 35, L19603, doi:10.1029/2008GL035028, 2008.

Booth, B. C. and Horner, R. A.: Microalgae on the Arctic Ocean section, 1994: species abundance and biomass, Deep Sea Res. II, 44(8), 1607-1622, doi:10.1016/S09670645(97)00057-X, 1997.

Benson, B. B. and Krause Jr, D.: The Concentration and Isotopic Fractionation of Oxygen Dissolved in Freshwater and Seawater in Equilibrium with the Atmosphere, Limnol. Oceanogr., 29(3), 620-632, 1984.

20 Cai, W. J., Chen, L., Chen, B., Gao, Z., Lee, S. H., Chen, J., Pierrot D., Sullivan, K., Wang, Y., Hu, X., Huang, W. J., Zhang, Y., Xu, S., Murata, A., Grebmeier, J. M., Jones, E. P., and Zhang, H.: Decrease in the CO2 uptake capacity in an ice-free Arctic Ocean Basin, Science, 329, 556-559, doi:10.1126/science.1189338, 2010.

Carmack, E. C., Macdonald, R. W., and Jasper, S.: Phytoplankton productivity on the Canadian

\section{Phytoplankton distribution in the Western Arctic Ocean}

P. Coupel et al.

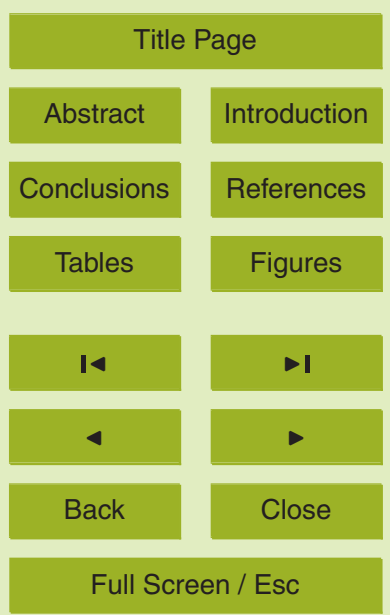

Printer-friendly Version

Interactive Discussion 
Clay, B. L., Kugrens, P., and Lee, R. E.: A revised classification of Cryptophyta, Bot. J. Linn. Soc., 131, 131-151, doi:10.1111/j.1095-8339.1999.tb01845.x, 1999.

Coachman, L. K. and Barnes, C. A.: The contribution of Bering Sea water to the Arctic, Department of Oceanography, Univ. of Wash., 249 pp., 1961.

5 Coachman, L. K., Aagaard, K., and Tripp, R. B.: Bering Strait: The Regional Physical Oceanography, Univ. of Wash. Press, Seattle, 1975.

Comiso, J. C., Parkinson, C. L., Gersten, R., and Stock, L.: Accelerated decline in the Arctic sea ice cover, Geophys. Res. Lett., 35, L01703, doi:10.1029/2007GL031972, 2008.

Cota, G. F., Pomeroy, L. R., Harrison, W. G., Jones, E. P., Peters, F., Sheldon, W. M., and Weingartner, T. R.: Nutrients, primary production and microbial heterotrophy in the southeastern Chukchi Sea: Arctic summer nutrient depletion and heterotrophy, Mar. Ecol. Prog. Ser., 135, 247-258, 1996.

Gordon, L. I., Jennings Jr., J. C., Ross, A. A., and Krest, J. M.: A suggested protocol for continuous flow automated analysis of seawater nutrients (Phosphate, Nitrate, Nitrite and

15 Silicic Acid) in the WOCE Hydrographic Program and the Joint Global Ocean Fluxes Study, WOCE Hydrographic Program Office, Methods Manual WHPO 91-1, 1993.

Gosselin, M., Levasseur, M., Wheeler, P. A., Horner, R. A., and Booth, B. C.: New measurements of phytoplankton and ice algal production in the Arctic Ocean, Deep Sea Res. II, 44, 1623-1644, 1997.

20 Gradinger, R. R. and Baumann, M. E. M.: Distribution of phytoplankton communities in relation to the large-scale hydrographical regime in the Fram Strait, Mar. Biol., 111, 311-321, 1991.

Grasshoff, K., Ehrhardt, M., and Kremling, K.: Methods of seawater analysis, 2nd ref. Edn., Verlag Chemie GmbH, Weinheim, 419 pp., 1983.

Grebmeier, J. M., Cooper, L. W., Feder, H. W., and Sirenko, B. I.: Ecosystem dynamics of the Pacific-influenced Northern Bering and Chukchi Seas in the Amerasian Arctic, Prog. Oceanogr., 71(2-4), 331-361, 2006a.

Grebmeier, J. M, Overland, J. E., Moore, S. E., Farley, E. V., Carmack, E. C., Cooper, L. W., Frey, K. E., Helle, J. H., McLaughlin, F. A., and McNutt, S. L.: A major ecosystem shift in the northern Bering Sea, Science, 311, 1461-1464, 2006b.

so Hameedi, M. J.: Aspects of water column primary productivity in the Chukchi Sea during summer, Mar. Biol., 48, 37-46, 1978.

Hill, V. and Cota, G. F.: Spatial patterns of primary production on the shelf, slope and basin of the Western Arctic in 2002, Deep Sea Res. II, 52, 3344-3354, 2005.

\section{BGD}

8, 6919-6970, 2011

\section{Phytoplankton distribution in the Western Arctic Ocean}

P. Coupel et al.

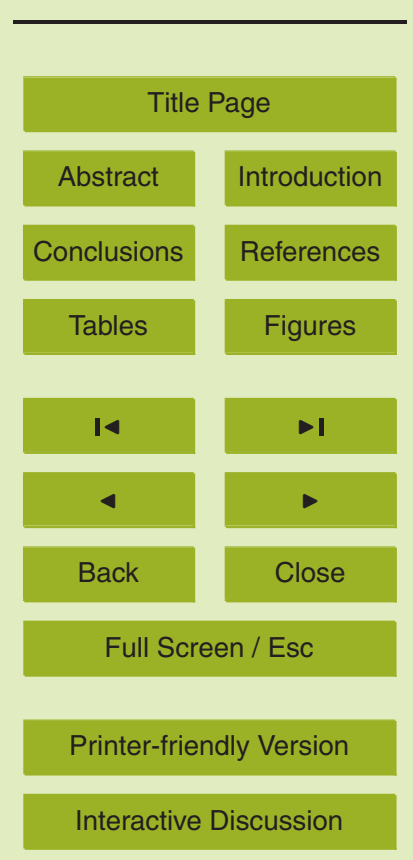


Hill, V., Cota, G., and Stockwell, D.: Spring and summer phytoplankton communities in the Chukchi and Eastern Beaufort Seas, Deep Sea Res. II, 52, 3369-3385, doi:10.1016/j.dsr2.2005.10.010, 2005.

Holland, M., Bitz, C. M., and Tremblay, B.: Future abrupt reductions in the summer Arctic sea ice, Geophys. Res. Lett., 33, L23503, doi:10.1029/2006GL028024, 2006.

Hunt Jr., G. L., Stabeno, P. J., Walters, G., Sinclair, E., Brodeur, R. D., Napp, J. M., and Bond, N. A.: Climate change and control of the southeastern Bering Sea pelagic ecosystem, Deep Sea Res. II, 49, 5821-5823, 2002.

Jeffrey, S. W. and Humphrey, G. F.: New spectrophotometric equations for determining chlorophylls $a, b, c 1$ and $c 2$ in higher plants, algae and natural phytoplankton, Biochem. Physiol. Pflanz., 1975.

Jeffrey, S. W. and Vesk, M.: Introduction to marine phyto plankton and their pigment signatures, in: Phytoplankton Pigments in Oceanography, edited by: Jeffrey, S. W., Mantoura, R. F. C., and Wright, S. W., UNESCO, Paris, 37-84, 1997.

15 Jones, E. P., Anderson L. G., Jutterstrom S., Mintrop L., and Swift J. H.: Pacific freshwater, river water and sea ice meltwater across Arctic Ocean basins, Results from the 2005 Beringia Expedition. J. Geophys. Res., 113, C08012, doi:10.1029/2007JC004124, 2008.

Lee, S. H., Joo, H. M., Liu, Z., Chen, J. F., and He, J. F.: Phytoplankton productivity in newly opened waters of the Western Arctic Ocean, Deep Sea Res. II, in press, doi:10.1016/j.dsr2.2011.06.005, 2011a.

Lee, S. H., Stockwell, D., and Whitledge, T. E.: Uptake rates of dissolved inorganic carbon and nitrogen by under-ice phytoplankton in the Canada Basin in summer 2005, Polar Biol., 33, 1027-1036, 2011b.

Lindsay, R. W. and Zhang J.: The thinning of Arctic sea ice, 1988-2003: Have we reached the tipping point?, J. Climate, 18, 4879-4895, 2005.

Li, W. K., McLaughlin, F. A., Lovejoy, C., and Carmack, E. C.: Smallest algae thrive as the Arctic Ocean freshens, Science, 326, 539, doi:10.1126/science.1179798, 2009.

Longhurst, A. R. and Harrison W. G.: The biological pump: profiles of plankton production and consumption in the upper ocean, Prog. Oceanogr., 22, 47-123, 1989.

30 Mackey, M. D., Mackey, D. J., Higgins, H. W., and Wright, S. W.: CHEMTAX - a program for estimating class abundances from chemical markers: Application to HPLC measurements of phytoplankton, Mar. Ecol. Prog. Ser., 144, 265-283, 1996.

Melnikov, I. A. and Bondarchuk, L. L.: To the ecology of the mass aggregations of colonial
BGD

8, 6919-6970, 2011

\section{Phytoplankton distribution in the \\ Western Arctic Ocean}

P. Coupel et al.

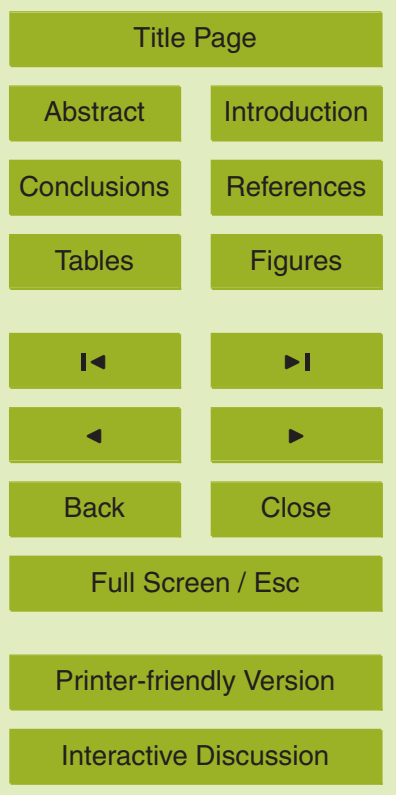


diatom algae under the Arctic drifting sea ice, Oceanology, 27(2), 317-321, 1987.

McLaughlin, F. A. and Carmack, E. C.: Deepening of the nutricline and chlorophyll maximum in the Canada Basin interior, 2003-2009, Geophys. Res. Lett., 37, L24602, doi:10.1029/2010GL045459, 2010.

5 Napp, J. M. and Hunt Jr., G. L.: Anomalous conditions in the south-eastern Bering Sea, 1997: linkages among climate, weather, ocean, and biology, Fish. Oceanogr., 10, 61-68, 2001.

Nishino, S., Shimada, K., Itoh, M., Yamamoyo-Kawai, M., and Chiba, S.: East-west differences in water mass, nutrient, and chlorophyll a distributions in the sea ice reduction region of the western Arctic Ocean, J. Geophys. Res., 113, C00A01, doi:10.1029/2007JC004666, 2008.

Overland, J. E. and Wang, M.: Future regional Arctic sea ice declines, Geophys. Res. Lett., 34, L17705, doi:10.1029/2007GL030808, 2007.

Pabi, S., van Dijken, G. L., and Arrigo, K. R.: Primary production in the Arctic Ocean, 19982006, J. Geophys. Res., 113, C08005, doi:10.1029/2007JC004578, 2008.

Paquette, R. G. and Bourke R. H.: Observations on the coastal current of arctic Alaska, J. Mar.

15 Res., 32, 195-207, 1974.

Parsons, T. R., Maita, Y., and Lalli, C. M.: A manual of chemical and biological methods for seawater analysis, Pergamon Press: Oxford, UK, ISBN 0-08-030287-4, XIV, 173 pp., 1984.

Piepenburg, P.: Recent research on Arctic benthos: common notions need to be revised, Polar Biol., 28, 733-755, doi:10.1007/s00300-005-0013-5, 2005.

20 Pickart, R. S.: Shelfbreak circulation in the Alaskan Beaufort Sea, Mean structure and variability, J. Geophys. Res., 109(C4), C04024, doi:10.1029/2003JC001912, 2004.

Pickart, R. S., Weingartner, T. J., Pratt, L. J., Zimmermann, S., and Torres, D. J.: Flow of winter-transformed water into the western Arctic, Deep Sea Res. II, 52, 3175-3198, 2005.

Proshutinsky, A., Bourke, R. H., and McLaughlin, F. A.: The role of the Beaufort Gyre in Arctic climate variability: Seasonal to decadal climate scales, Geophys. Res. Lett., 29(23), 2100, doi:10.1029/2002GL015847, 2002.

Proshutinsky, A., Krishfield, R., Timmermans, M. L., Toole, J., Carmack, E., McLaughlin, F., Williams, W. J., Zimmermann, S., Itoh, M., and Shimada, K.: Beaufort Gyre freshwater reservoir: State and variability from observations, J. Geophys. Res., 114, C00A10, doi:10.1029/2008JC005104, 2009.

Rabe, B., Karcher, M., Schauer, U., Toole, J., Krishfield, R., Pisarev, S., Kauker, F., Gerdes, R., and Kikuchi, T.: An assessment of pan-Arctic Ocean freshwater content changes from the 1990s to the IPY period, Deep Sea Res. I., 58, 173-185, 2011.

\section{BGD}

8, 6919-6970, 2011

\section{Phytoplankton distribution in the Western Arctic Ocean}

P. Coupel et al.

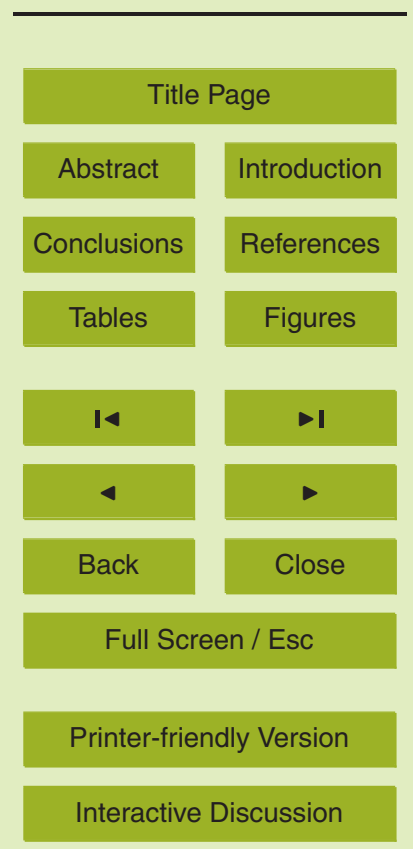


Ras, J., Claustre, H., and Uitz, J.: Spatial variability of phytoplankton pigment distributions in the Subtropical South Pacific Ocean: comparison between in situ and predicted data, Biogeosciences, 5, 353-369, doi:10.5194/bg-5-353-2008, 2008.

Redfield, A., Ketchum, B. H., Richards, F. A.: The influence of organisms on the composition of 5 seawater, in: The Sea, edited by: Hill, M. N., Academic Press, New York, 26-77, 1963.

Rothrock, D. A., Yu, Y., and Maykut, G. A.: Thinning of the Arctic sea-ice cover, Geophys. Res. Lett., 26(23), 3469-3472, 1999.

Rysgaard, S., Kuhl, M., Glud, R. N., and Hansen, J. W.: Biomass, production and horizontal patchiness of sea ice algae in a high-Arctic fjord (Young Sound, NE Greenland), Mar. Ecol.

10 Prog. Ser., 223, 15-26, 2001.

Sakshaug, E.: Primary and secondary production in Arctic Seas, in: The Organic Carbon Cycle in the Arctic Ocean, edited by: Stein, R. and Macdonald, R. W., Springer, Berlin, 57-81, 2003.

Sakshaug, E., Bjørge, A., Gulliksen, B., Loeng, H., and Mehlum, F.: Structure, biomass dis15 tribution, and energetics of the pelagic ecosystem in the Barents Sea: a synopsis, Polar Biology, 14, 405-411, 1994.

Schlitzer, R., Ocean Data View 4, available at: http://odv.awi.de (last access: 15 April 2011), 2010.

Shimada, K., Carmack, E. C., Hatakeyama, K., and Takizawa, T.: Varieties of shallow temperature maximum waters in the western Canadian Basin of the Arctic Ocean, Geophys. Res. Lett., 28, 3441-3444, 2001.

Shimada, K., Itoh, M., Nishino, S., McLaughlin, F., Carmack, E., and Proshutinsky, A.: Halocline structure in the Canada Basin of the Arctic Ocean, Geophys. Res. Lett., 32, L03605, doi:10.1029/2004GL021358, 2005.

Springer, A. M., McRoy, C., and Flint, M. V.: The Bering Sea green belt: shelf edge processes and ecosystem production, Fish. Oceanogr., 5, 205-223, 1996.

Stockwell, D. A., Whitledge, T. E., Zeeman, S. I., Coyle, K. O., Napp, J. M., Brodeur, R. D., Pinchuk, A. I., and Hunt Jr., G. L.: Anomalous conditions in the south-eastern Bering Sea, 1997: nutrients, phytoplankton, and zooplankton, Fish. Oceanogr., 10, 99-116, 2001.

so Stroeve, J. C., Serreze M. C., Fetterer, F., Arbetter, T., Meier, W., Maslanik, J., and Knowles, K.: Tracking the Arctic's shrinking ice cover: Another extreme September minimum in 2004, Geophys. Res. Lett., 32, L04501, doi:10.1029/2004GL021810, 2005.

Stroeve, J., Holland, M. M., Meier, W., Scambos, T., and Serreze, M. C.: Arctic sea ice decline:

\section{BGD}

8, 6919-6970, 2011

\section{Phytoplankton distribution in the Western Arctic Ocean}

P. Coupel et al.

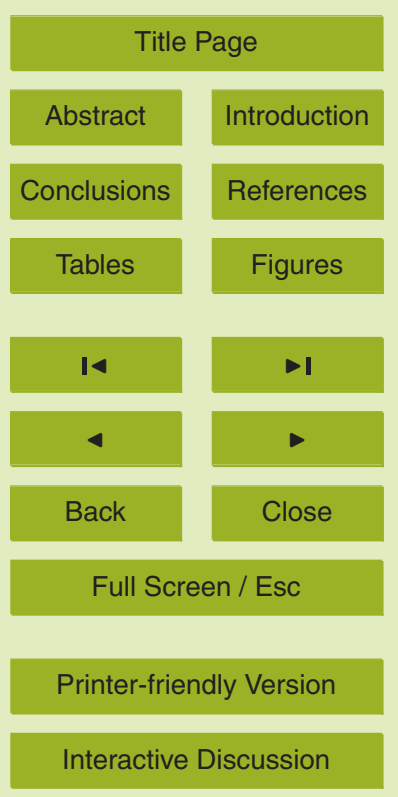


Faster than forecast, Geophys. Res. Lett., 34, L09501, doi:10.1029/2007GL029703, 2007.

Sukhanova, I. N. and Flint, M. V.: Anomalous blooming of coccolithophorids over the eastern Bering Sea shelf, Oceanology, 38, 502-505, 1998.

Sukhanova, I. N., Flint, M. V., Pautova, L. A., Stockwell, D. A., Grebmeier, J. M., and Sergeeva,

$5 \quad$ V. M.: Phytoplankton of the western arctic in the spring and summer of 2002: structure and seasonal changes, Deep-Sea Res. II, 56, 1223-1236, doi:10.1016/j.dsr2.2008.12.030, 2009.

Toole, J. M., Timmermans, M. L., Perovich, D. K., Krishfield, R. A., Proshutinsky, A., and Richter-Menge, J. A.: Influences of the ocean surface mixed layer and thermohaline stratification on Arctic Sea ice in the central Canada Basin, J. Geophys. Res., 115, C10018, doi:10.1029/2009JC005660, 2010.

Vance, T. C., Baier, C. T., Brodeur, R. D., Coyle, K. O., Decker, M. B., Hunt Jr., G. L., Napp, J. M., Schumacher, J. D., Stabeno, P. J., Stockwell, D., Tynan, C. T., Whitledge, T. E., Wyllie, Echeverria, T., and Zeeman, S.: Aquamarine waters recorded for first time in eastern Bering

15 Sea, EOS, Trans. Am. Geophys. Union, 79, 121-126, 1998.

Van Heukelem, L. and Thomas, C. S.: Computer-assisted high -performance liquid chromatography method development with applications to the isolation and analysis of phytoplankton pigments, J. Chromatogr. A, 910, 31-49, 2001.

Walsh, J. J.: Arctic carbon sinks: present and future, Global Biogeochem. Cy., 3, 393-411, 1989.

Wassmann, P., Duarte, C. M., Agusti, S., and Sejr, M. K.: Footprints of climate change in the Arctic marine ecosystem, Glob. Change Biol., 17, 1235-1249, doi:10.1111/j.13652486.2010.02311, 2010.

Weingartner, T. J., Cavalieri, D. J., Aagaard, K., and Sasaki, Y.: Circulation, dense water formation, and outflow on the northeast Chukchi shelf, J. Geophys. Res., 103, 7647-7662, 1998.

Weingartner, T., Aagaard, K., Woodgate, R., Danielson, S., Sasaki, Y., and Cavalieri, D.: Circulation on the north central Chukchi Sea shelf, Deep-Sea Res. II, 52, 3150-3174, 2005.

Wood, E. D., Armstrong, F. A. J., and Richards, F. A.: Determinations of nitrate in sea water by 30

\section{BGD}

8, 6919-6970, 2011

\section{Phytoplankton distribution in the Western Arctic Ocean}

P. Coupel et al.

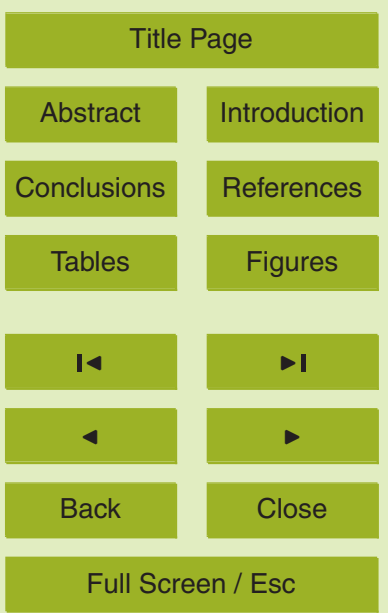

Printer-friendly Version

Interactive Discussion 


\section{BGD}

8, 6919-6970, 2011

Table 1. List of the pigments used in this study and theirs taxonomic significance. P: Picoplankton $(<2 \mu \mathrm{m}), \mathrm{N}$ : Nanoplankton $(2-20 \mu \mathrm{m}), \mathrm{M}$ : Microplankton $(>20 \mu \mathrm{m})$.

\begin{tabular}{llll}
\hline Pigments & Abbreviation & $\begin{array}{l}\text { Size } \\
\text { Classes }\end{array}$ & $\begin{array}{l}\text { Taxonomic } \\
\text { significance }\end{array}$ \\
\hline Chlorophyll-c3 & Chl-c3 & & Prymnesiophytes, Chrysophytes \\
Chlorophyll-c2 & Chl-c2 & All & Various \\
Peridinin & Peri & M & Dinoflagellates \\
$19^{\prime}$-Butanoyloxyfucoxanthin & But & $\mathrm{N}$ & Chrysophytes, Haptophytes \\
Fucoxanthin & Fuco & $\mathrm{M}$ & Diatoms, prymnesiophytes, some Dinoflagellates \\
Neoxanthin & Neo & $\mathrm{P}$ & Chlorophytes \\
Prasinoxanthin & Pras & $\mathrm{P}$ & Prasinophytes \\
Violaxanthin & Viola & $\mathrm{P}$ & Chlorophytes, Prasinophytes \\
19'-Hexanoyloxyfucoxanthin & Hex & $\mathrm{N}$ & Prymnesiophytes \\
Diadinoxanthin & Diadino & All & Various \\
Alloxanthin & Allo & $\mathrm{P}+\mathrm{N}$ & Cryptophytes \\
Diatoxanthin & Diato & All & Various \\
Zeaxanthin & Zea & $\mathrm{P}$ & Cyanobacteria, Prochlorophytes, Chlorophytes \\
Lutein & Lut & $\mathrm{P}+\mathrm{N}$ & Red algae, Chlorophytes \\
Chlorophyll- $b$ & Chl- $b$ & $\mathrm{P}+\mathrm{N}$ & Green algae \\
Divinyl Chlorophyll-a & Dvchl-a & $\mathrm{P}$ & Prochlorophytes \\
$\beta-$ Carotenes & Car & All & Various \\
Chlorophyll-a & Chla & All & All - except Prochlorophytes \\
\hline
\end{tabular}

\section{Phytoplankton distribution in the} Western Arctic Ocean

P. Coupel et al.

Title Page

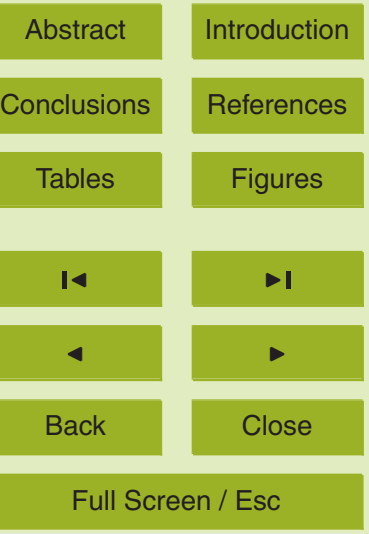

Printer-friendly Version

Interactive Discussion 
BGD

8, 6919-6970, 2011

\section{Phytoplankton distribution in the}

Western Arctic Ocean

P. Coupel et al.

Table 2. Table referencing physical and biogeochemical parameters for the eight provinces visited during the CHINARE 2008 cruise.

\begin{tabular}{|c|c|c|c|c|c|c|c|c|c|c|c|}
\hline & Latitude & $\begin{array}{l}\text { Ice } \\
\text { cover } \\
\%\end{array}$ & Date & $\begin{array}{l}\text { PWW } \\
\text { depth } \\
\text { (m) }\end{array}$ & $\begin{array}{l}\text { SFL } \\
\text { thickness } \\
(\mathrm{m})\end{array}$ & SI & $\begin{array}{l}\text { Nitrate } \\
(\mu \mathrm{M})\end{array}$ & $\begin{array}{l}\text { Surface } \\
\text { Chl- } a \\
\left(\mathrm{mg} \mathrm{chl}-\mathrm{a} \mathrm{m}^{-3}\right)\end{array}$ & $\begin{array}{l}\text { SCM } \\
\text { Chl-a } \\
\left(\mathrm{mg} \mathrm{chl}-\mathrm{am}^{-3}\right)\end{array}$ & $\begin{array}{l}\text { SCM } \\
\text { depth } \\
(\mathrm{m})\end{array}$ & $\begin{array}{l}\mathrm{PP}_{\text {eu }} \\
\left(\mathrm{mgC} \mathrm{m}^{-3} \mathrm{~h}^{-1}\right)\end{array}$ \\
\hline Chukchi Shelf & $68-73^{\circ} \mathrm{N}$ & $10 \pm 20$ & 01-06 Aug & 15 & 5 & 1.5 & 4.6 & $0.91 \pm 0.89$ & $1.61 \pm 1.55$ & 22 & $2.050 \pm 2.150$ \\
\hline Slope/Shelf break & $72-74^{\circ} \mathrm{N}$ & 0 & 08-10 Aug & 40 & 30 & 5 & 2.2 & $0.11 \pm 0.08$ & $0.64 \pm 0.60$ & 40 & $0.100 \pm 0.077$ \\
\hline CB (ice-free) & $74-78^{\circ} \mathrm{N}$ & $4 \pm 9$ & 10-14 Aug & 150 & 55 & 6 & 0.8 & $0.03 \pm 0.03$ & $0.34 \pm 0.28$ & 60 & $0.009 \pm 0.001$ \\
\hline Borderland (ice-free) & $75-78^{\circ} \mathrm{N}$ & 0 & 01-03 Sept & 60 & 30 & 3 & 3.2 & $0.06 \pm 0.04$ & $0.41 \pm 0.26$ & 35 & $0.027 \pm 0.007$ \\
\hline $\mathrm{CB}$ (partially ice covered) & $78-83^{\circ} \mathrm{N}$ & $67 \pm 10$ & 14-18 Aug & 100 & 30 & 3 & 2.7 & $0.05 \pm 0.02$ & $0.49 \pm 0.09$ & 40 & $0.022 \pm 0.008$ \\
\hline AMZ & $78-83^{\circ} \mathrm{N}$ & $50 \pm 23$ & 03-06 Sept & 80 & 15 & 2 & 3.6 & $0.21 \pm 0.07$ & $0.53 \pm 0.26$ & 25 & $0.110 \pm 0.043$ \\
\hline CB (Heavy ice) & $83-86^{\circ} \mathrm{N}$ & $80 \pm 10$ & 18-31 Aug & 100 & 60 & 4 & 0.15 & $0.06 \pm 0.03$ & $0.21 \pm 0.11$ & 55 & 0.013 \\
\hline
\end{tabular}

Title Page

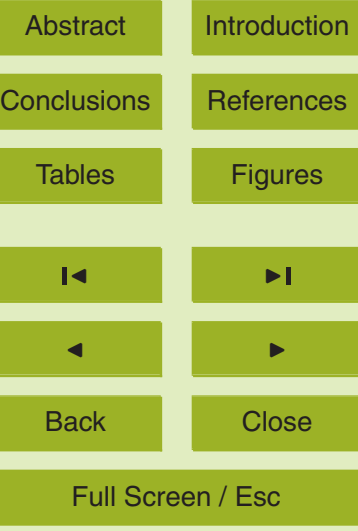

Printer-friendly Version

Interactive Discussion 

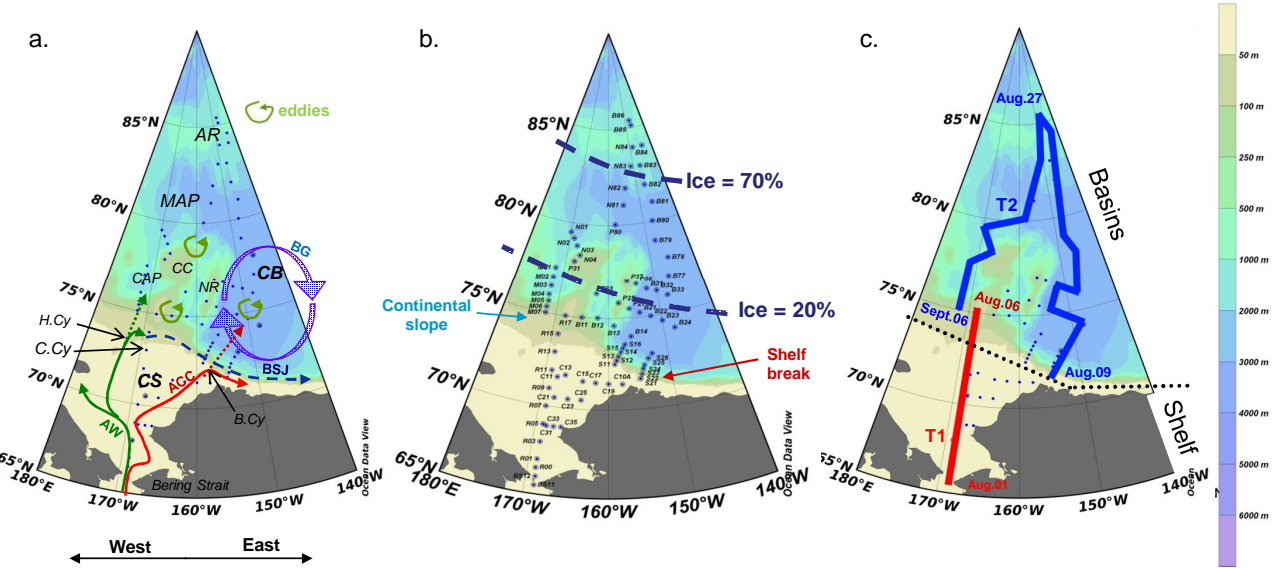

Fig. 1. (a) Bathymetry, circulation and main topographic features of the study area. CS: Chukchi Shelf, CB: Canadian Basin, MAP: Mendeleev Abyssal Plain, AR: Alpha Ridge, CC: Chukchi Cap, NR: Northwind Ridge, CAP: Chukchi Abyssal Plain, B.Cy: Barrow Canyon, H.Cy: Herald Canyon, C.Cy: Central Canyon. The Chukchi Borderland includes the CC, the NR and the CAP. BG: Beaufort Gyre, AW: Anadyr Water, ACC: Alaskan Coastal Current, BSJ: Chukchi/Beaufort Shelfbreak Jet. (b) Location and name of the CTD stations visited during the CHINARE 2008 cruise aboard "XueLong" icebreaker between 1 August and 8 September 2008. Limit of ice concentration $20 \%$ and $70 \%$ are indicated on the map by dashed blue line. (c) Location of both transects discussed in section 4 and presented in Fig. 11 (Transect 1) and Fig. 12 (Transect 2). The transect 1 (red) describes the Chukchi Shelf (CS) and the transect 2 (blue) describes the offshore conditions encompassing the Canadian Basin, the Alpha Ridge and the Chukchi Borderland $(\mathrm{CC}+\mathrm{CAP}+\mathrm{NR})$.
BGD

8, 6919-6970, 2011

\section{Phytoplankton distribution in the Western Arctic Ocean}

P. Coupel et al.

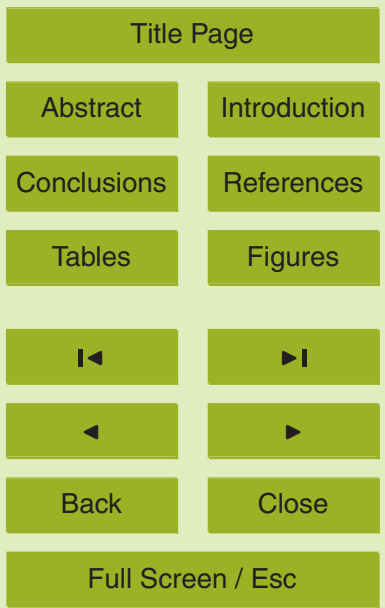

Printer-friendly Version

Interactive Discussion 
a.
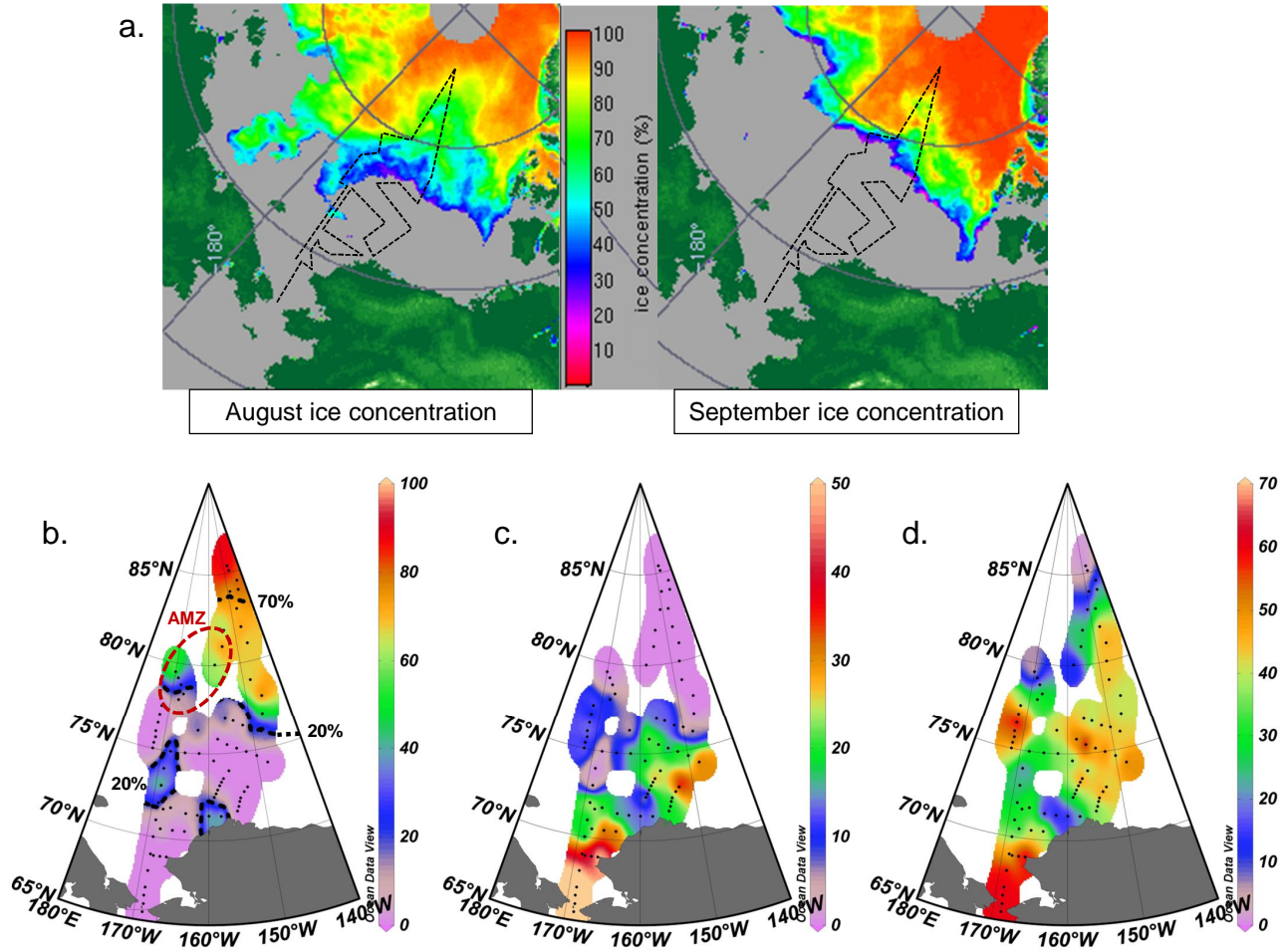

Fig. 2. (a) Monthly Western Arctic ice concentrations from SSMI for August 2008 and September 2008. The dashed line represents the CHINARE 2008 cruise track. (b) Seven days average ice concentration (\%). The dashed red circle represents the Active Melting Zone (AMZ). (c) Number of days with ice-free conditions since visit of CTD station. (d) Number of days with ice concentrations lowers than $90 \%$ since visit of CTD station.

\section{BGD}

8, 6919-6970, 2011

\section{Phytoplankton distribution in the Western Arctic Ocean \\ P. Coupel et al.}

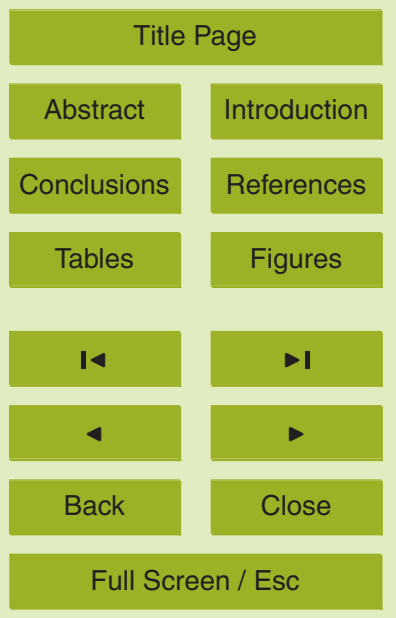

Printer-friendly Version

Interactive Discussion 

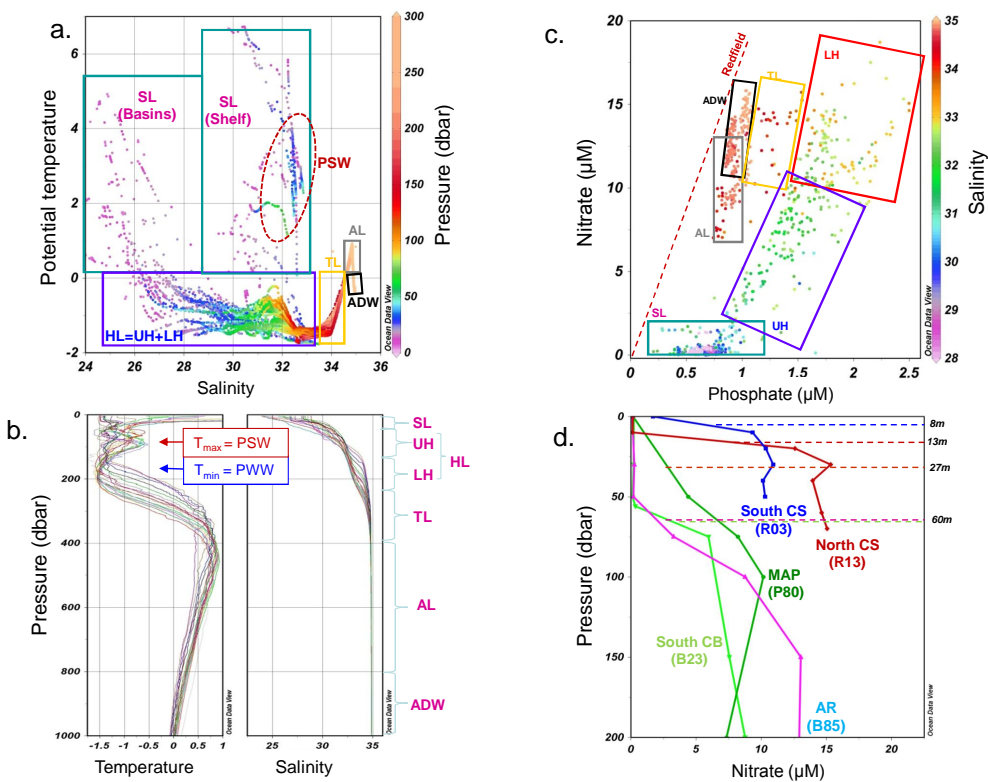

BGD

8, 6919-6970, 2011

\section{Phytoplankton distribution in the Western Arctic Ocean}

P. Coupel et al.

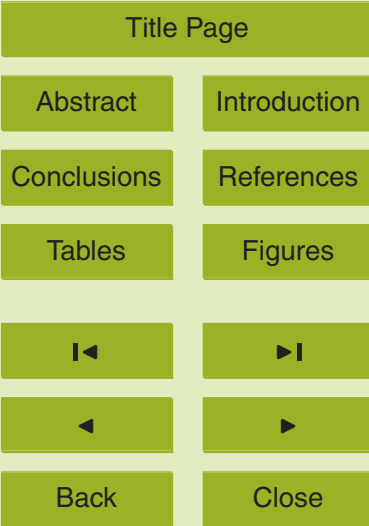

Full Screen / Esc

Printer-friendly Version

Interactive Discussion 


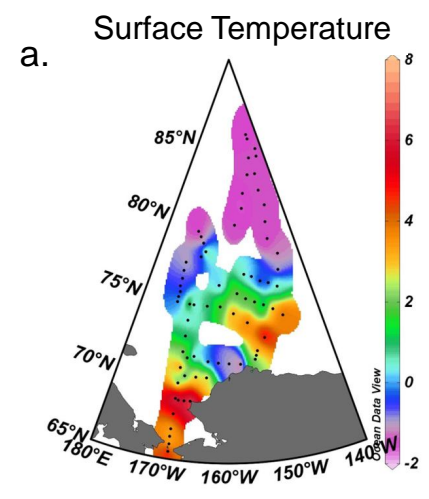

Polar Mixed Layer (m)

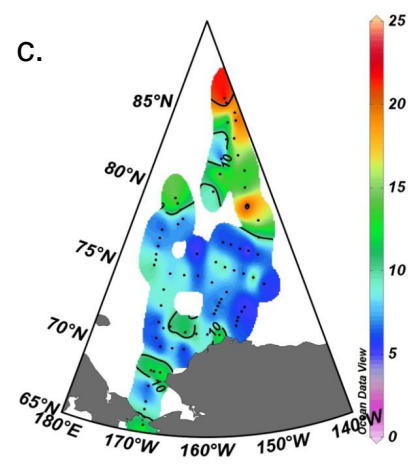

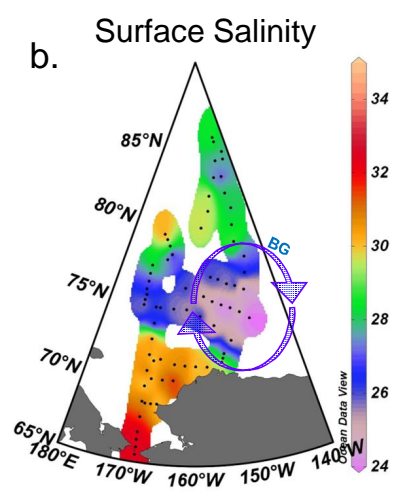

Stratification Index

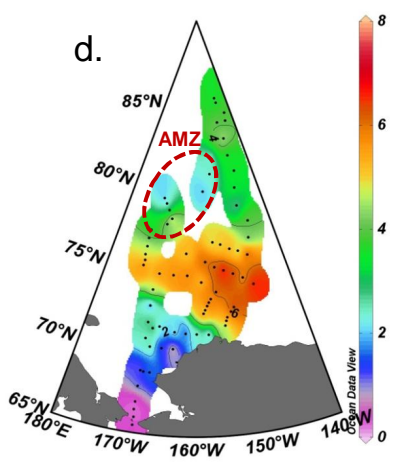

BGD

8, 6919-6970, 2011

\section{Phytoplankton distribution in the} Western Arctic Ocean

P. Coupel et al.

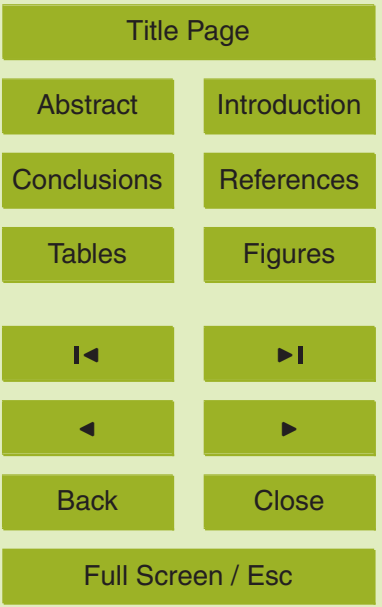

Printer-friendly Version

Interactive Discussion

Fig. 4. (a) Surface potential temperature at $3 \mathrm{~m}$ in ${ }^{\circ} \mathrm{C}$; (b) surface salinity at $3 \mathrm{~m}$ with position of the Beaufort Gyre (BG); (c) polar mixed layer depth (PML); (d) stratification index in $\mathrm{kg} \mathrm{m}^{-3}$ with position of the Active Melting Zone (AMZ) indicated by the red dashed circle. 

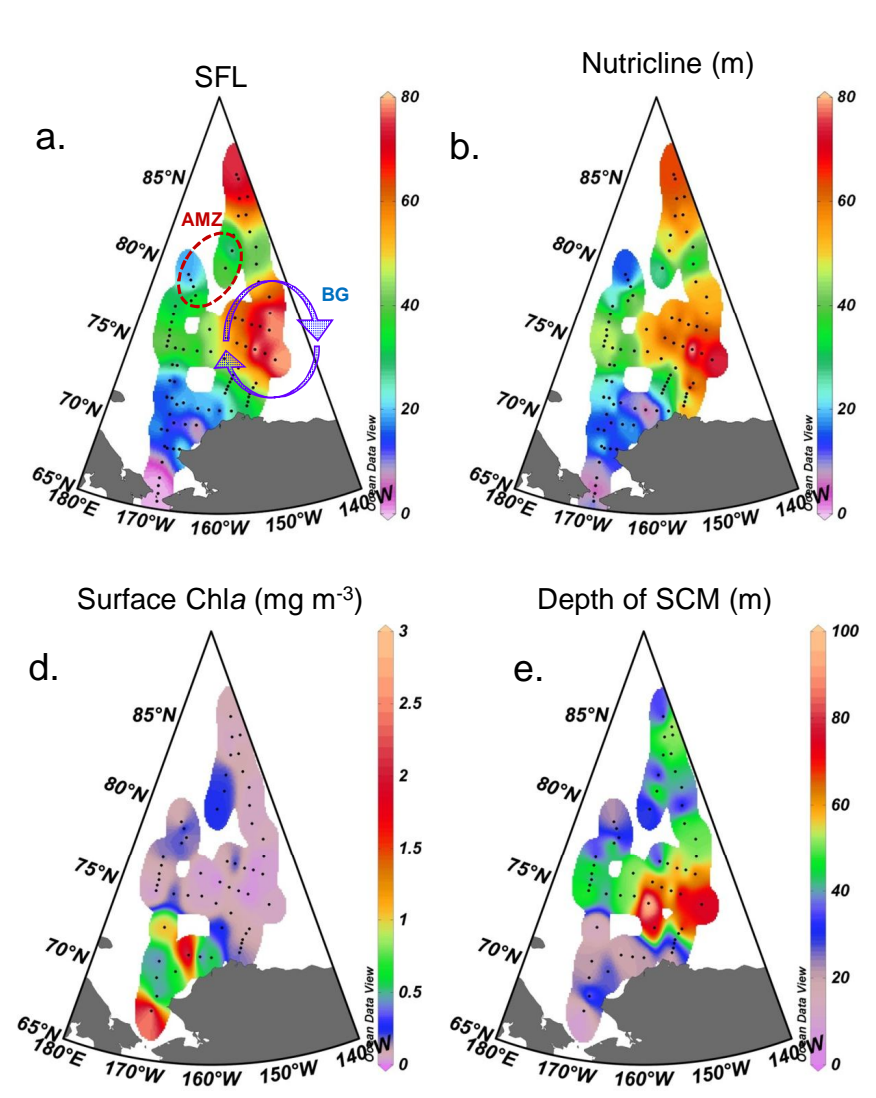

Average nitrate

concentrations $(\mu \mathrm{M})$

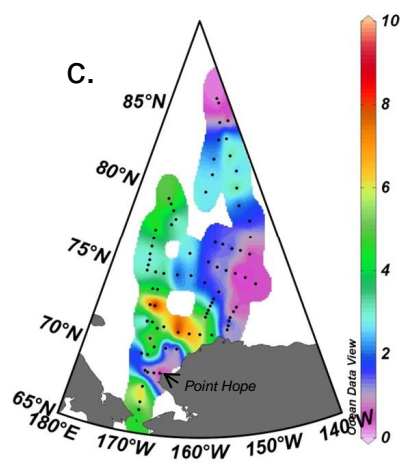

SCM Chla $\left(\mathrm{mg} \mathrm{m}^{-3}\right)$

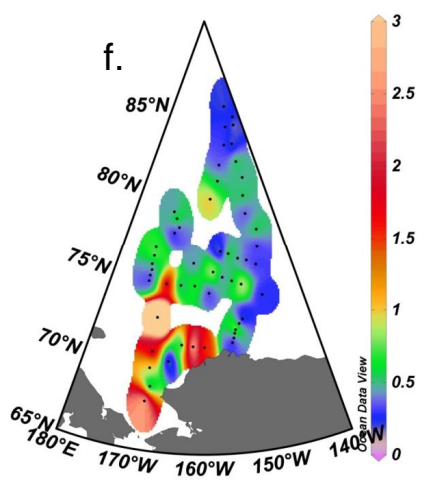

\section{BGD}

8, 6919-6970, 2011

\section{Phytoplankton distribution in the Western Arctic Ocean \\ P. Coupel et al.}

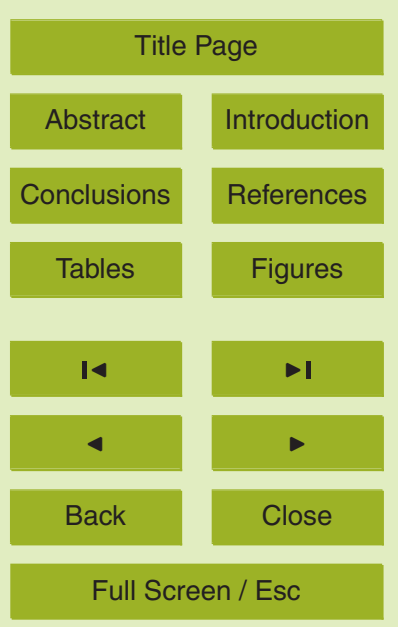

Printer-friendly Version

Fig. 5. (a) SFL: Surface Freshwater Layer $(m)$ with position of the Beaufort Gyre (BG) and the Active Melting Zone (AMZ); (b) nutricline depth (m); (c) average nitrate concentrations within the euphotic depth $(\mu \mathrm{M})$; (d) surface chlorophyll-a concentration $\left(\mathrm{mg} \mathrm{m}^{-3}\right)$; (e) depth of the sub-surface chlorophyll maxima $(\mathrm{m})$; (f) sub-surface maximum of chlorophyll-a concentration $\left(\mathrm{mg} \mathrm{m}^{-3}\right)$. 


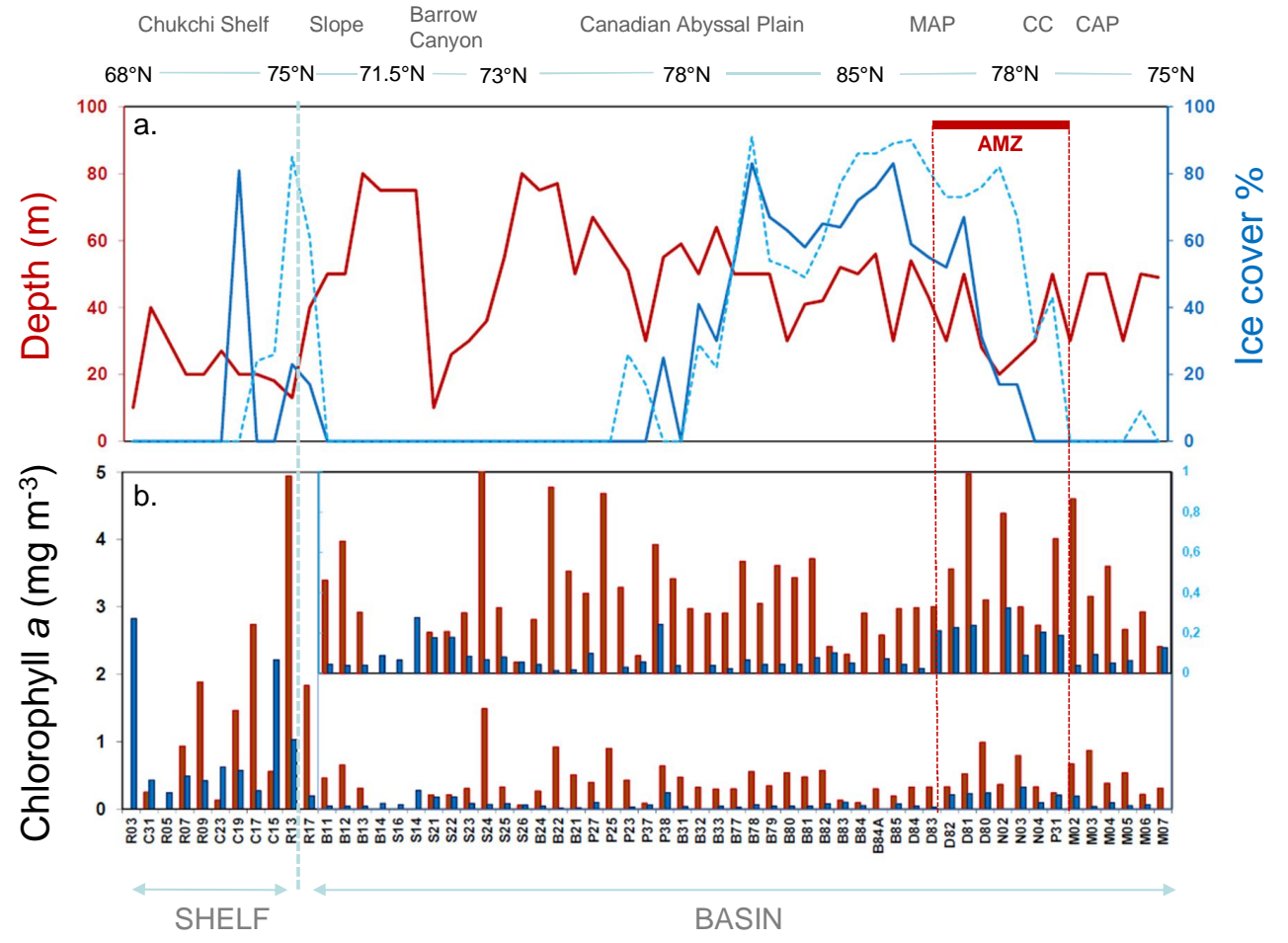

Fig. 6. (a) Percentage of ice covers (blue line) prevailing along the ship track and 7 days before the visit of the ship (dashed blue line) and depth of the SCM (red line). AMZ: Active Melting Zone. (b) In-situ Chl-a concentrations $\left(\mathrm{mg} \mathrm{m}^{-3}\right.$ ) along the ship track in surface (blue) and at SCM (red). The small panel represents a zoom $\left(0\right.$ to $\left.1 \mathrm{mg} \mathrm{m}^{-3}\right)$ of the chl-a concentrations over the open basins.
BGD

8, 6919-6970, 2011

Phytoplankton distribution in the Western Arctic Ocean

P. Coupel et al.

\section{Title Page}

Abstract Introduction

Conclusions References

Tables

Figures

14

$>1$

4

Back

Close

\section{Full Screen / Esc}

Printer-friendly Version

Interactive Discussion 


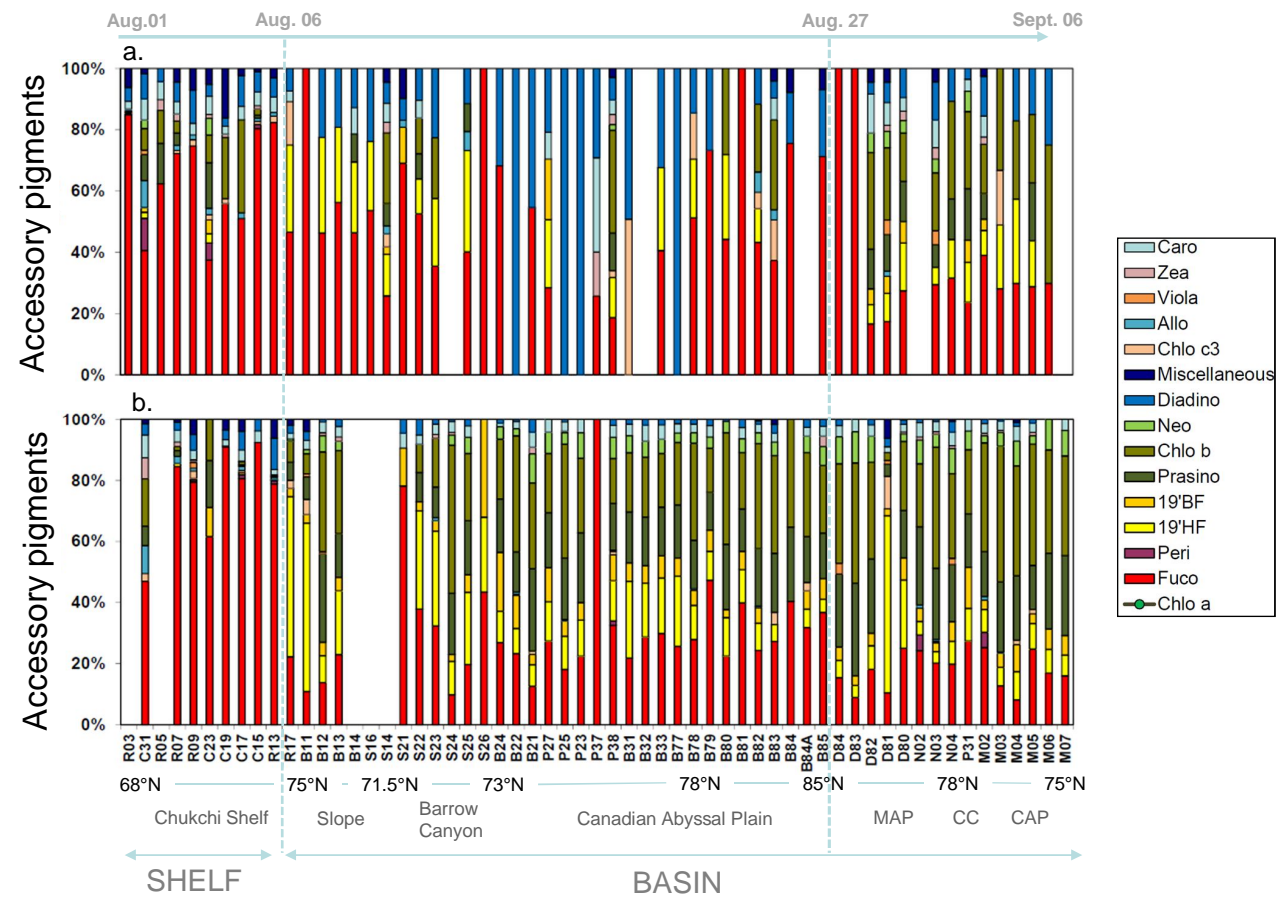

BGD

8, 6919-6970, 2011

\section{Phytoplankton distribution in the Western Arctic Ocean \\ P. Coupel et al.}

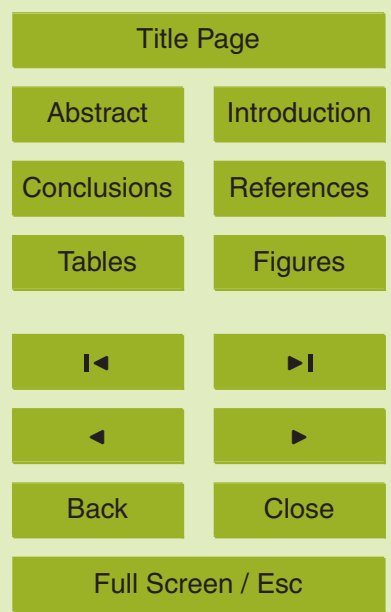

Fig. 7. Percentage contribution of the major diagnostic pigments to the total accessory pigment load at the CHINARE stations and within provinces: (a) surface, (b) SCM. The pigments abbreviations are indicated in Table 1. The miscellaneous group refers to pigments measured in proportion less than $2 \%$ at each station (Chl-c2, Diato, Lut, Dvchl-a). 

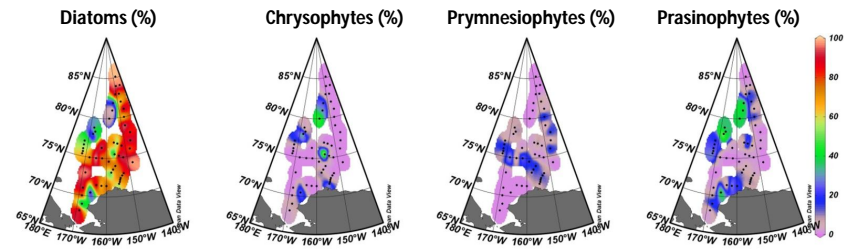

Dinoflagellates (\%)

Cryptophytes (\%)
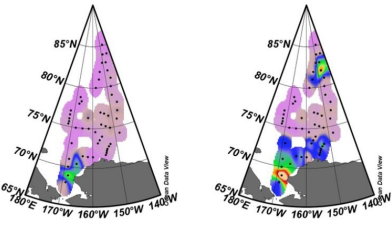

Diatoms (\%)
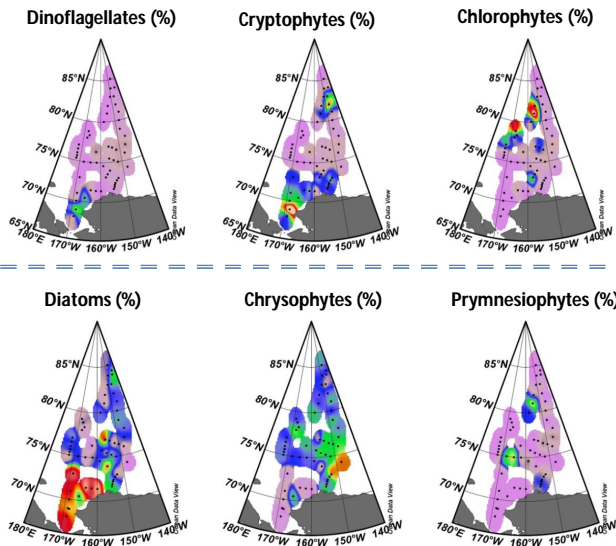

Cyanobacteria $(\%)$

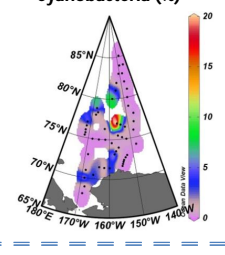

Prymnesiophytes (\%)

Prasinophytes (\%)

Dinoflagellates $(\%)$
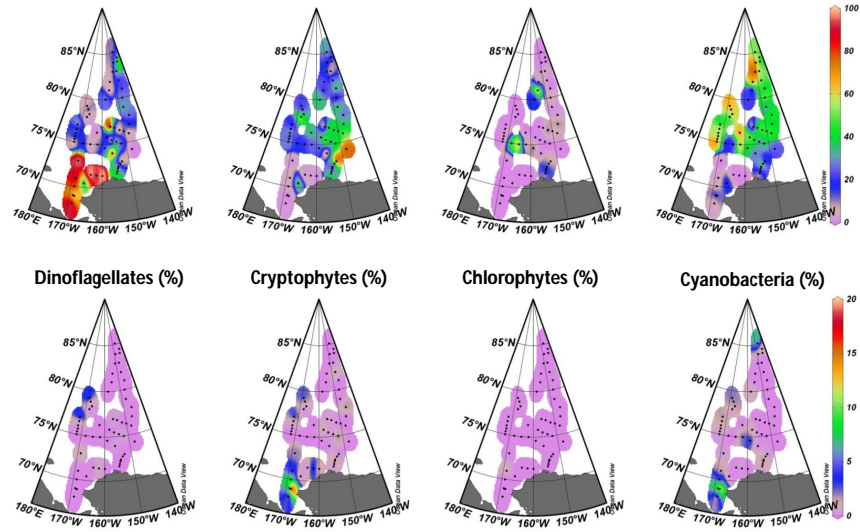

Fig. 8. Percentage contribution of the main phytoplankton groups derived from CHEMTAX to the total phytoplankton communities at surface (8 top maps) and at SCM (8 bottom maps). Note the scales are from 0 to $100 \%$ for Diatoms, Chrysophytes, Prymnesiophytes and Prasinophytes and from 0 to $20 \%$ for Dinoflagellates, Cryptophytes, Chlorophytes and Cyanobacteria.
BGD

$8,6919-6970,2011$

\section{Phytoplankton distribution in the} Western Arctic Ocean

P. Coupel et al.

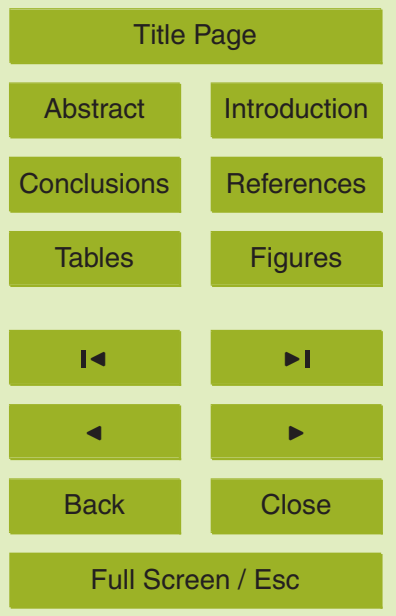

Printer-friendly Version

Interactive Discussion 
a.

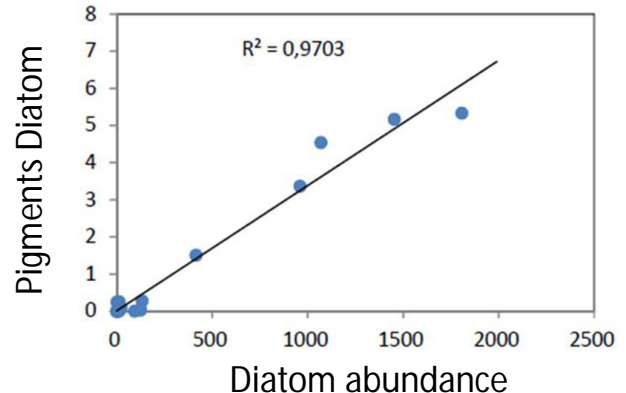

b.

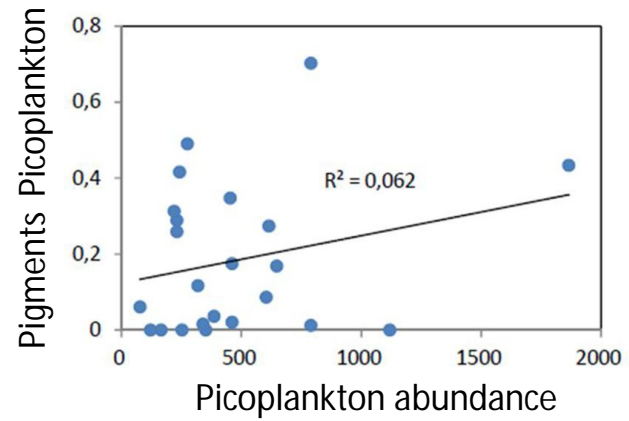

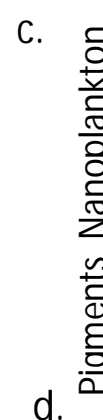
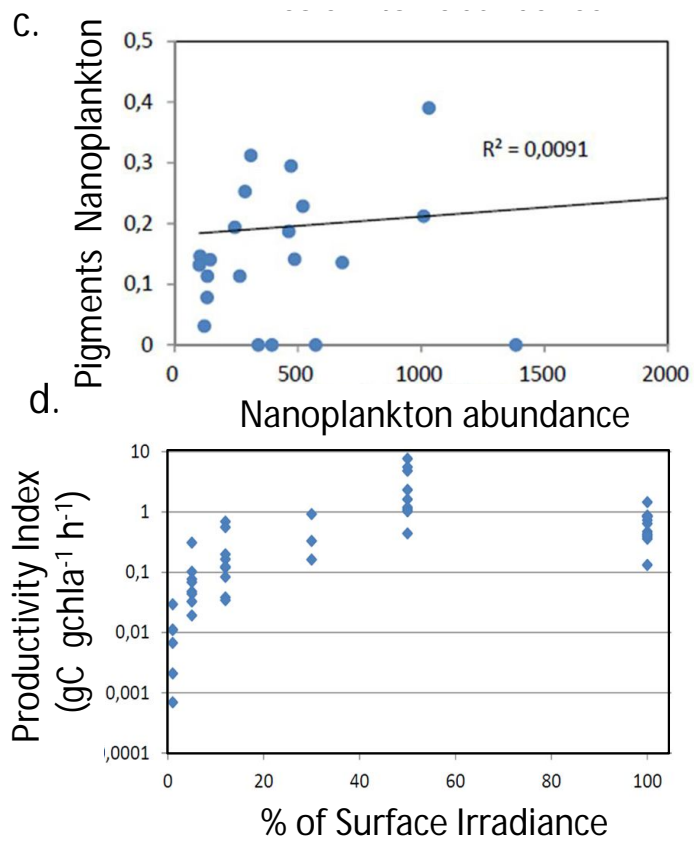

Fig. 9. Pigments contribution $\left(\mathrm{mg} \mathrm{m}^{-3}\right.$ ) against cell number (cells $\mathrm{ml}^{-1}$ ) for specific phytoplankton classes identified by light microscopy and CHEMTAX: (a) "Diatoms", (b) "Picoplankton", (c) "Nanoplankton". (d) Productivity index (PP/[Chl-a]) as a function of percentage of the surface irradiance.
BGD

8, 6919-6970, 2011

\section{Phytoplankton} distribution in the Western Arctic Ocean

P. Coupel et al.

\section{Title Page}

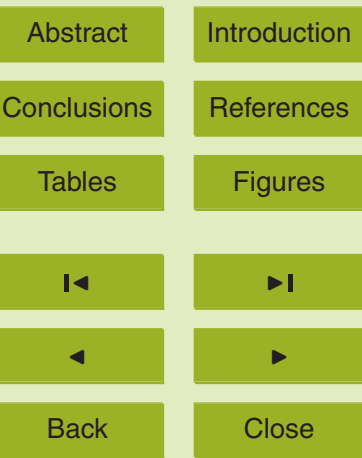

Full Screen / Esc

Printer-friendly Version

Interactive Discussion 


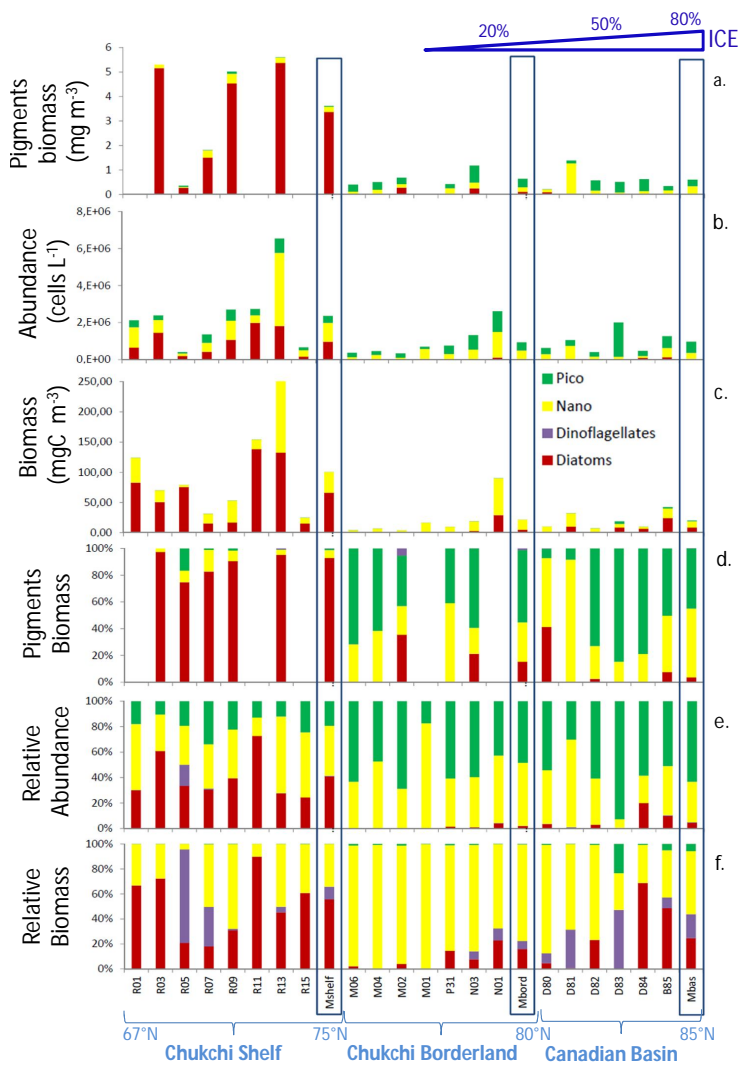

Fig. 10. Contribution of 4 major phytoplankton classes (Picoplankton, Nanoplankton, Dinoflagellates, Diatoms) in terms of (a) biomass of specific pigments allocated to each group by CHEM$\operatorname{TAX}\left(\mathrm{mg} \mathrm{m}^{-3}\right)$ (b) cell abundance (cells $\left.\mathrm{I}^{-1}\right)$ (c) carbon biomass $\left(\mathrm{mg} \mathrm{C} \mathrm{m}^{-3}\right)$ and relative contribution of the 4 groups to (d) total accessory pigments biomass (\%) (e) total cell abundance (\%) (f) and total phytoplankton carbon biomass (\%).
BGD

8, 6919-6970, 2011

Phytoplankton distribution in the Western Arctic Ocean

P. Coupel et al.

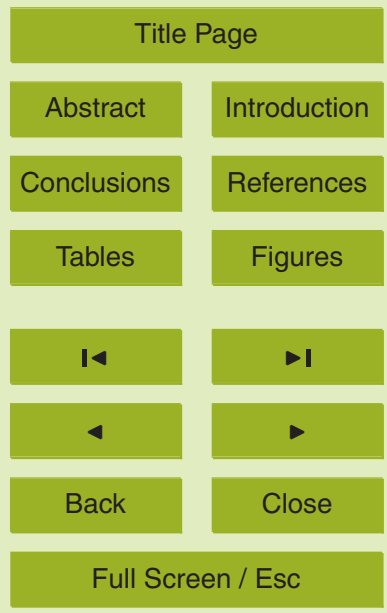

Printer-friendly Version

Interactive Discussion 


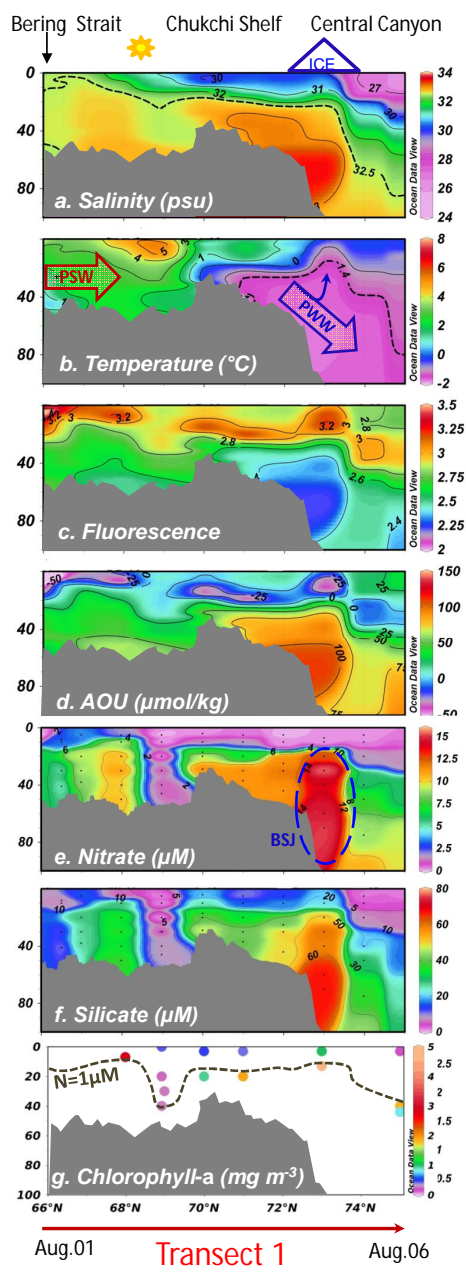

\section{BGD}

8, 6919-6970, 2011

\section{Phytoplankton distribution in the} Western Arctic Ocean

P. Coupel et al.

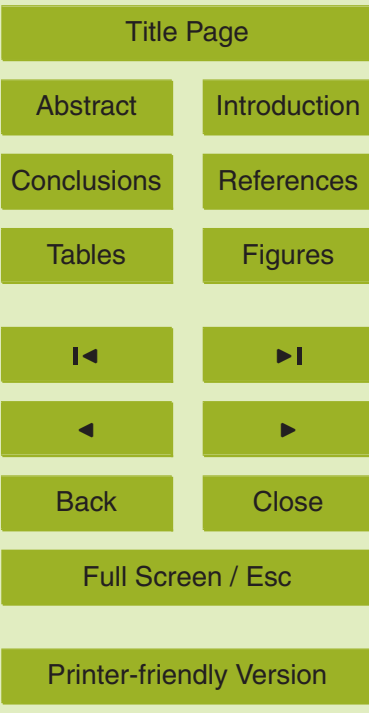

Interactive Discussion

Fig. 11. Caption on next page. 


\section{Phytoplankton distribution in the Western Arctic Ocean \\ P. Coupel et al.}

Fig. 11. Vertical section of the upper $100 \mathrm{~m}$, across the transect 1 presented in Fig. 1c, for (a) salinity, (b) temperature $\left({ }^{\circ} \mathrm{C}\right)$, (c) fluorescence (arbitrary units), (d) AOU (Apparent Oxygen Utilization in $\left.\mu \mathrm{mol} \mathrm{kg}^{-1}\right)$, (e) nitrate concentration $(\mu \mathrm{M})$, (f) silicate concentration $(\mu \mathrm{M}),(\mathbf{g})$ Chla concentration $\left(\mathrm{mg} \mathrm{m}^{-3}\right)$. Main topographic features and ice cover are indicated at the top of the sections. PSW (Pacific Summer Water), PWW (Pacific Winter Water), BSJ (Beaufort Shelfbreak Jet) are indicated on section. The black bold dashed line in sections (g) represents the position of the nitracline where nitrate concentrations equal $1 \mu \mathrm{M}$.

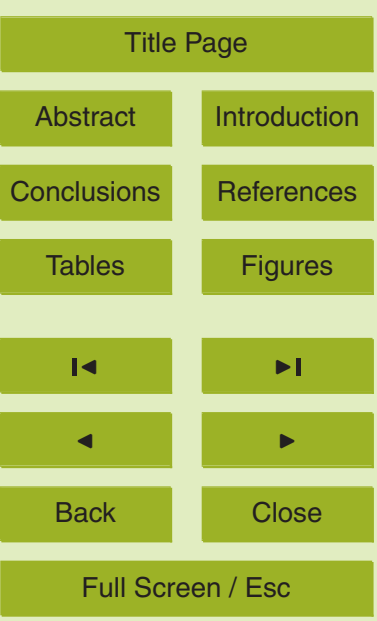

Printer-friendly Version

Interactive Discussion 


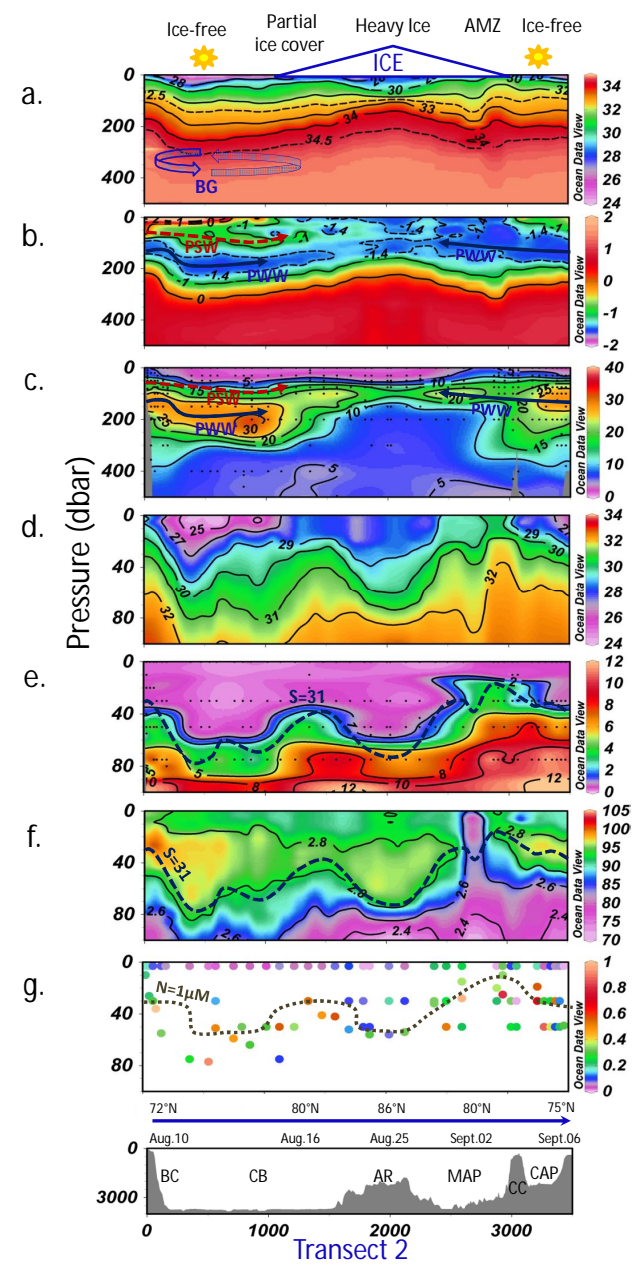

BGD

8, 6919-6970, 2011

\section{Phytoplankton distribution in the Western Arctic Ocean}

P. Coupel et al.

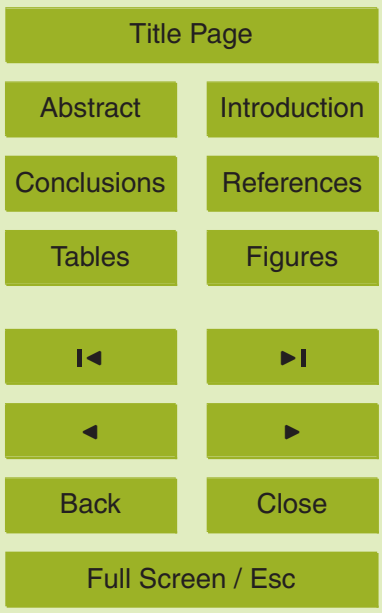

Printer-friendly Version

Interactive Discussion

Fig. 12. Caption on next page. 


\section{Phytoplankton distribution in the Western Arctic Ocean \\ P. Coupel et al.}

Fig. 12. Vertical sections, along transect 2 presented in Fig. 1c, of the upper $500 \mathrm{~m}$ (a) salinity, (b) temperature $\left({ }^{\circ} \mathrm{C}\right)$, (c) silicate concentration $(\mu \mathrm{M})$ and of the upper $100 \mathrm{~m}$ (d) salinity, (e) nitrate concentration $(\mu \mathrm{M})$, (f) Oxygen saturation (\%) overlay with fluorescence isoline (g) Chl-a concentration $\left(\mathrm{mg} \mathrm{m}^{-3}\right)$. Ice conditions are indicated at the top of the sections and defined in "ice-free" conditions (<20\%), AMZ (Active melting zone, 20-70\%), Partial ice cover (20-70\%) and heavy ice conditions ( $>70 \%)$. Input of PSW and PWW are represented by red and blue arrows respectively. The SFL depth $(S=31)$ is indicated by a blue dashed line on section (e) and $\mathbf{( f )}$. The black bold dashed line in section $(\mathbf{g})$ represents the position of the nitracline where nitrate concentrations equal $1 \mu \mathrm{M}$.

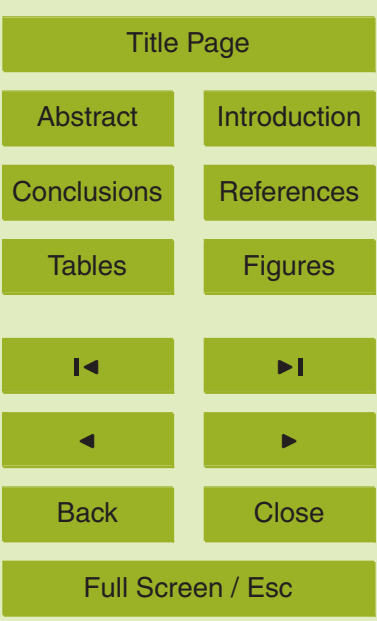

Printer-friendly Version

Interactive Discussion 